Sławomir Łotysz

Instytut Historii Nauki im. L. i A. Birkenmajerów PAN

\title{
TRANSEUROPEJSKA DROGA WODNA PRZEZ POLESIE A KWESTIA JEGO OSUSZENIA W II RZECZPOSPOLITEJ
}

The trans-European waterway through Poland and the question of reclaiming the Polesie marshes in the interwar period

The reclamation of the Pinsk marshes, as envisaged in interwar Poland, was one of the most ambitious national investment projects of the era. The plan was closely linked with the concept of a trans-European waterway running through Polesie, that was also being contemplated around that time. The latter project was embedded in a larger discussion about Poland's inland navigation. Eventually, neither of these projects were finalized or even begun, before the second world war broke out. This paper analyses the discourse that took place on both issues, with a particular focus on their inevitable intersection. While describing the political background of this discourse, the article reconsiders the role of the engineers as the principal, sometimes overlooked, players in these processes. This research was supported by the National Science Centre, Poland, Grant No. 2015/19/B/HS3/03553

Keywords: waterways, inland navigation, land reclamation, Poland's Second Republic Słowa kluczowe: drogi wodne, żegluga śródlądowa, melioracje rolne, II Rzeczpospolita

\section{Wstęp}

W 1936 r. wybitny polski hydrotechnik prof. Mieczysław Rybczyński, pisząc na łamach „Gospodarki Wodnej”, przedstawił swój pogląd na kwestię zależności pomiędzy budową dróg wodnych na Polesiu a osuszaniem tamtejszych bagien. Ten wieloletni prezes Polskiego Towarzystwa Geofizycznego, w latach 1922-1926 kierujący pracami Ministerstwa Robót Publicznych w kilku kolejnych rządach, stwierdzał: 
Przecież tam [na Polesiu] roboty melioracyjne są tak ściśle związane z komunikacjami, że każdy nowy kanał osuszający staje się drogą wodną dla okolicznych mieszkańców, pozbawionych najczęściej najprymitywniejszych dróg. Z drugiej strony nie można ani rzek regulować, ani budować sztucznych dróg wodnych bez równoczesnego osuszania przyległych obszarów ${ }^{1}$.

Z twierdzeniem tym można zgodzić się jedynie częściowo. Analiza przebiegu publicznych dyskusji, jakie w II Rzeczpospolitej toczyły się wokół obu tych zagadnień (a tym bardziej - na styku między nimi), wskazuje, że zależność ta była daleko bardziej złożona i nie zawsze tak jednoznaczna, jak uważał Rybczyński. Dotychczasowe piśmiennictwo dotyczące zarówno osuszenia Polesia, jak i rozbudowy krajowej sieci dróg wodnych - dwóch nigdy nie zrealizowanych wielkich przedsięwzięć modernizacyjnych II Rzeczpospolitej - jest niezwykle skromne, toteż artykuł ten opiera się w głównej mierze na dokumentach z epoki, przede wszystkim na czasopiśmiennictwie technicznym, ale sięgnięto również do sprawozdań stenograficznych z posiedzeń Sejmu, memoriałów i opisów projektów dróg wodnych autorstwa inżynierów polskich i niemieckich oraz do prasy codziennej. Chociaż oba te wątki pojawiają się we współczesnej historiografii, wspominane są niejako z kronikarskiego obowiązku lub na marginesie zagadnień stanowiących główne pole obserwacji większości badaczy ${ }^{2}$. Rozpoznanie przebiegu oraz tła obu tych dyskursów wymaga wejrzenia w motywacje i przesłanki, jakimi kierowali się ich uczestnicy, głównie inżynierowie, choć w sprawę zaangażowani byli również politycy i wojskowi.

Oba przedsięwzięcia były planowane z niezwykłym rozmachem i - jeśli zrealizowane - mogły wywrzeć ogromny wpływ na dalszy rozwój kraju. Z tego też powodu skupiały uwagę nie tylko środowisk inżynierskich, lecz także polityków, wojskowych oraz ogółu społeczeństwa. Osuszenie Polesia było jednym z najambitniejszych przedsięwzięć hydrotechnicznych planowanych w II Rzeczpospolitej. Chodziło o zmeliorowanie 1,5 mln hektarów podmokłych terenów i osiedlenie tam miliona osadników z przeludnionych województw zachodnich i południowych. Zamierzenie to porównywano niekiedy do budowy portu w Gdyni, po części z racji zbliżonych

\footnotetext{
${ }^{1}$ M. Ry b c z y ń s ki : Administracja wodna w Polsce, „Gospodarka Wodna” t. 2:1936 nr 1 s. 4.

${ }^{2}$ Wątek prac nad osuszeniem Polesia poruszyli m. in.: J. To m a s z e w s k i : $Z$ dziejów Polesia 1921-1939: zarys stosunków społeczno-ekonomicznych, Warszawa 1963; M. Ła pa: Modernizacja państwa: polska polityka gospodarcza 1926-1929, Łódź 2002; W. Śleszyński: Bezpieczeństwo wewnętrzne $w$ polityce państwa polskiego na ziemiach północno-wschodnich II Rzeczypospolitej, Warszawa 2007; P. Ci c h or a cki : Droga ku anatemie: Wacław Kostek-Biernacki (1884-1957), Warszawa 2009. Ogólne uwarunkowania polityczno-prawne międzywojennych starań o rozbudowę krajowej sieci dróg wodnych przedstawia, $\mathrm{m}$. in. Z. M i ku l s ki : Wkład Polaków w rozwój hydrologii i inżynierii wodnej. Początki służby hydrologicznej na ziemiach polskich, w: Z. M i kul s ki (red.): Wkład Polaków w rozwój hydrologii i inżynierii wodnej, Warszawa 2008; A. M a g n u s z e w s ki: Rozwój żeglugi śródlądowej w Polsce, tamże. Historie poszczególnych dzieł hydrotechnicznych tamtego okresu w swoich pracach zawarli m.in.: J. Z ał łę c z ny : Powiat warszawski w latach II Rzeczypospolitej, Warszawa 2015.
} 
kosztów inwestycji, które szacowano na blisko pół miliarda złotych. Lwią część tych wydatków miała pochłonąć regulacja poleskich rzek i budowa kanałów, które poza umożliwieniem odwodnienia bagien mogły służyć jako dogodne drogi komunikacyjne - byłaby to okoliczność nie do przecenienia w przypadku realizacji planu kolonizacji tych ziem. Z melioracją Polesia łączył się szeroko dyskutowany w tym samym czasie plan budowy przez te tereny tzw. transeuropejskiej drogi wodnej, która - jak to niekiedy obrazowo przedstawiano - miała połączyć centra przemysłowe Europy od Pirenejów aż po Ural. Według niektórych wersji droga ta miała przebiegać albo skanalizowaną Prypecią, albo kanałem lateralnym - bocznym kanałem żeglownym prowadzonym nieco na południe od tej rzeki.

Ostatecznie w okresie międzywojennym nie zmeliorowano Polesia ani nie zbudowano przezeń międzynarodowej drogi wodnej. W przypadku pierwszego przedsięwzięcia przeważyło zdanie kół wojskowych, które w tamtejszych bagnach widziały skuteczną zaporę przed ewentualną agresją strony Związku Radzieckiego. Natomiast co się tyczy kwestii budowy przez Polesie drogi wodnej, w całym okresie międzywojennym politycy i inżynierowie nie osiągnęli zgody nawet co do tego, czy byłaby ona dla Polski szansą czy zagrożeniem.

W artykule dokonano rekonstrukcji chronologii działań podejmowanych wówczas przez władze państwowe oraz inne podmioty, jak przedsiębiorstwa prywatne i samorządy. Kluczowe jest ukazanie tych wydarzeń w szerszym kontekście dyskursów (naukowo-technicznego, politycznego, gospodarczego), jaki na temat rozbudowy krajowej sieci dróg wodnych toczył się wówczas w Polsce. Artykuł stawia tezę, że zasadniczym powodem niepowodzenia obu tych projektów było to, że przez cały okres międzywojenny nie stworzono w Polsce podstaw spójnej i długofalowej gospodarki wodnej.

\section{Polesie w sieci europejskich dróg wodnych}

Do końca XIX w. rozwój europejskich dróg wodnych odbywał się w sposób dość spontaniczny, nieregularny i miał charakter lokalny. Specyficzne warunki przyrodnicze i wpisujące się w nie miejscowe relacje gospodarcze sprawiły, że w początkach XX w. funkcjonowało w Europie pięć dużych sieci dróg wodnych, w zasadzie mających ze sobą niewielką łączność: zachodnioeuropejska (obejmująca rzeki Francji, zachodnich Niemiec oraz Belgii i Holandii), środkowoeuropejską (obejmującą Łabę, Odrę, Wisłę i Niemen), dunajską (Dunaj z dopływami), ukraińską (Dniepr, Dniestr i Don) i rosyjską (Wołga, Newa i Dźwina) ${ }^{3}$. Były to w zasadzie odrębne systemy komunikacyjne, a połączenia między nimi powstawały stosunkowo opornie - choćby z uwagi na trudności techniczne związane z pokonaniem zwykle dość wysokich wo-

\footnotetext{
${ }^{3}$ S. T u r c z y n o w i c z, T. T ill i n g e r: Konieczność budowy drogi wodnej przez Polesie i osuszania go celem połączenia zachodnich centrów przemysłowych ze źródłami surowców środkowej i wschodniej Europy, Warszawa 1925, s. 16.
} 
dodziałów czy ze względu na nie mniej trudne do pokonania przeszkody natury politycznej. W efekcie większość towarów pomiędzy obszarami obsługiwanymi przez te systematy przewożono kolejami lub drogą morską.

Niemniej pod koniec XIX w. w zachodnioeuropejskich kręgach gospodarczych, zaczęła dojrzewać koncepcja budowy drogi wodnej łączącej kontynent od Pirenejów po Ural. Prym w forsowaniu tej idei wiedli Niemcy, budując Mittellandkanal (w piśmiennictwie polskim nazywany Śródlądowym lub Śródziemnym), który stanowił główną oś Zachód-Wschód, spinającą niemieckie drogi wodne, i którym - poprzez Kanał Bydgoski - statki i barki płynące z Zachodniej Europy mogły wpływaćaż na Wisłę. Większość tych koncepcji zakładała, że barki popłyną wówczas w górę Wisły, a stąd kanałami do Prypeci i dalej do Dniepru. Te ambitne plany rozbudowy infrastruktury transportowej na wschód od Niemiec wpisywały się w ówczesną politykę ekspansji politycznej i gospodarczej Berlina.

Trasa ta wydawała się oczywista, niejako podsunięta przez samą naturę. „Doskonałą równinność" Polesia - jak jego specyficzne ukształtowanie określał wybitny polski geograf prof. Stanisław Lencewicz (1889-1944) - na osi południkowej przecina wiele rzek, które zasilają płynącą z zachodu na wschód Prypeć, najważniejsze ujście dla wód opadowych z tego obszaru4. Na przedłużeniu tej osi, w kierunku zachodnim płynie wpadający w Brześciu do Bugu Muchawiec. To właśnie na granicy zlewni Muchawca i Prypeci - a raczej Wisły i Dniepru - znajduje się najniższy punkt wododziału bałtycko-czarnomorskiego wynoszący 144 metry5. Wprawdzie za łącznik pomiędzy obydwiema zlewniami mógłby służyć także Dunaj, ale stanowiska wododziałowe na ewentualnych kanałach łączących go z Renem, Łabą lub Odrą wypadają znacznie wyżej niż na Polesiu (odpowiednio 569, 370 i 265 m n.p.m.). Na to, że dzięki tym tzw. naturalnym wrotom poleskim krajowe drogi wodne mogą - i powinny - odgrywać ważną rolę w międzynarodowej żegludze, w swoim memoriale z 1925 r. zwracali uwagę Stanisław Turczynowicz i Tadeusz Tillinger6́.

Przed pierwszą wojną światową budowę połączenia pomiędzy ukraińską a środkowoeuropejską siecią dróg wodnych rozważali również Rosjanie. Choć dla nich droga łącząca Dniepr z Wisłą miała być arterią krajową, to poprzez Kanał Bydgoski

${ }^{4}$ S. Le ncewicz: Międzyrzecze Bugu i Prypeci Wody płynq̨ce i jeziora, „Przegląd Geograficzny" t. 11:1931 s. 1.

${ }^{5}$ Wprawdzie w opracowaniu Turczynowicza i Tillingera z 1925 r. kota wysokościowa dla tego stanowiska działowego została określona jako $140 \mathrm{~m}$ (S. T u r c z y n o w i c z, T. T ill in g e r: Konieczność..., s. 19), to jednak w późniejszych opracowaniach ten sam Tillinger dla istniejącego Kanału Królewskiego określał ją na 144 m (zob. T. T ill in g e r : Przyszłe drogi wodne na Ziemiach Zachodnich, „Prace Instytutu Badania Stanu Gospodarczego Ziem Wschodnich” t. 1:1927 nr 1 s. 36).

${ }^{6}$ S. Turczynowicz, T. Tillinger Konieczność budowy..., s. 19. Szerokiemu popularyzowaniu tej koncepcji, również za granicą, sprzyjało wydanie tej pracy również w języku angielskim. Zob. S. Turczyn ow icz, T. Tillinger The transeuropean waterway through Poland: by way of Polesie - its natural gate - and the necessity of draining that territory, Warszawa 1925. 
spięłaby wschód i zachód kontynentu. Opracowany w latach 1912-1916 projekt zakładał budowę drogi w klasie magistrali przystosowanej do ruchu jednostek o wyporności 100000 pudów (ok. 1700 ton)7. Od Dniepru jej trasa biegła Prypecią aż do ujścia Horynia, a stąd już kanałem lateralnym prowadzonym nieco na południe od Pińska i starego Kanału Królewskiego z pominięciem krętego biegu Muchawca wprost do Bugu. Kanał ten miał biec niemal w linii prostej i na jednym poziomie z minimalną liczbą śluz.

Wraz z wybuchem I wojny światowej rosyjskie plany straciły na aktualności. Niemieckie - przeciwnie. Berlinowi wojna upraszczała to, co w czasie pokoju wymagało poszukiwania kompromisów i zawierania bilateralnych porozumień bądź też podporządkowywania się szerszym, międzynarodowym konwencjom. Na początku 1918 r., po zawarciu traktatu brzeskiego, w którym państwa centralne formalnie uznawały istnienie niepodległej Ukrainy, budowa drogi wodnej stanowiącej przedłużenie Kanału Śródlądowego na wschód, stała się jednym z priorytetów Berlina, oferowała bowiem znaczne ułatwienie dostępu do ukraińskich surowców, a przede wszystkim produktów rolnych. Już nawet w traktacie brzeskim w zamian za uznanie swojej suwerenności i obietnicę pomocy militarnej Ukraińcy zobowiązali się do końca czerwca 1918 r. dostarczyć Niemcom i Austriakom milion ton zboża ${ }^{8}$.

Opracowaniem projektu takiej drogi wodnej już od pewnego czasu zajmował się inż. Paul Ehlers (1854-1934), profesor budownictwa wodnego na Politechnice Gdańskiej (Technischen Hochschule Danzig). W okresie, gdy pozycja militarna Niemców na froncie wschodnim zdawała się gwarantować utrzymanie zdobytych terytoriów, Ehlers opracował ogólną koncepcję dróg wodnych „na Wschodzie” jak to ujął w tytule swojej rozprawy ${ }^{9}$. Jej kluczowym elementem było przedłużenie Kanału Śródlądowego - jego trasa miała biec przez Wartę, Noteć i Kanał Bydgoski do Wisły, a stamtąd przez San do Dniestru. Co znamienne jednak, Niemcy nie chcieli ograniczać się do tego jednego połączenia. W swojej kolejnej pracy, ukończonej w sierpniu 1918 r., a zatem tuż przed tym, jak na froncie wschodnim państwom centralnym przestała sprzyjać fortuna, Ehlers przeanalizował inne możliwe warianty takiego połączenia ${ }^{10}$.

Tym samym tematem zajmowała się komisja gospodarcza niemieckiego parlamentu, która w końcu września 1918 r. wizytowała Prusy Wschodnie. W obliczu zarysowujących się, nieuchronnych i dość niekorzystnych dla siebie zmian geopolitycznych w tej części Europy Berlin poszukiwał możliwości bezpośredniego połączenia swojej sieci komunikacyjnej ze Wschodem. Sprawa ta miała dla Niemców

${ }^{7}$ T. Tilling e r: Przyszłe drogi... s. 36.

${ }^{8} \mathrm{~K}$. Grü n b e rg, B. S pr e n ge l: Trudne sq̨siedztwo : stosunki polsko-ukraińskie w X-XX wie$k u$, Warszawa 2005, s. 246.

${ }^{9}$ P. E h l e rs: Binnenwasserstraßen des Ostens : mit einem Längenschnitt und einer farbigen Karte, Danzig 1917.

${ }^{10}$ P. E h l e r s : Die Wasserstraße Danzig-Ukraine, Danzig 1918. 
wymiar „narodowy, polityczny i strategiczny”, ich zdaniem bowiem „powinno być z góry wyłączone, żeby jedyna wielka droga wodna między Białorusią i Ukrainą z jednej strony, a niemieckimi rynkami z drugiej, miała prowadzić przez Polskę"11. 0 ile w dążeniu do realizacji tego celu niemieckie działania były spójne i zdecydowane, to w kwestiach szczegółowych wyraźnie zarysowywała się rywalizacja Gdańska i Królewca o to, w którym z tych miast droga wodna łącząca Niemcy z Ukrainą i dalej - Morzem Czarnym weźmie swój początek. Władze miejskie oraz sfery gospodarcze w obu tych portach dążyły w ten sposób do zapewnienia sobie uprzywilejowanej pozycji w przyszłym handlu ze Wschodem ${ }^{12}$.

Ehlers, oprócz powtórzenia - odpowiednio austrowęgierskiego i rosyjskiego pomysłu połączenia Wisły z Sanem lub Dnieprem, postulował budowę drogi wodnej łączącej Gdańsk ze Śląskiem i tamtejszym zagłębiem węglowym. Droga miała zaczynać się w Bytomiu połączonym kanałem z Małą Panwią, a następnie biec przez Prosnę, Wartę i jezioro Gopło wprost do Wisły pod Toruniem ${ }^{13}$. Projekt ten został zaprezentowany w czerwcu 1917 r. na Międzynarodowym Zjeździe w Sprawie Budowy Dróg Wodnych w Wiedniu. Do pomysłu, aby śląski węgiel spławiać kanałem wprost do Gdańska, uczestników spotkania przekonywał radny z tego miasta, dr Alfred Evert. Używał przy tym argumentacji, która zwróciła uwagę jednego z polskich uczestników spotkania, inż. Józefa Bunda, referenta kolejowego z krakowskiej Izby Przemysłowo-Handlowej. Jak wspominał Bund, gdański radny „gloryfikował czasy, kiedy to Gdańsk, mając w Polsce i dalszym obszarze południowo-wschodnim rozległe zaplecze, kwitł jako największe imperium handlowe na Bałtyku"14. Zdaniem Everta, coraz powszechniejsza wówczas tendencja kierowania towarów pochodzących z ziem polskich do Hamburga i Szczecina była „właściwie zboczeniem z naturalnej drogi” łączącej Polskę z morzem i wyrażał nadzieję, że „po zwycięskim zakończeniu wojny" ta strefa gospodarczego oddziaływania zostanie reaktywowana otwierając tym samym drogę do „ponownego rozkwitu [Gdańska]”15.

\section{W poszukiwaniu wizji}

Po rychłym i rzeczywiście zwycięskim (choć zapewne nie po myśli Everta) zakończeniu wojny przed wyzwaniem zapewnienia spławu węgla i w ogóle przed

11 A. Prz.: Niedoszłe projekty kanałów wschodnio-pruskich, „Przegląd Techniczny” t. 57:1919 nr 29-32 s. 158. Notatka przytacza stwierdzenia zawarte w artykule „Zentralblatt für Wasserbau und Wasserwirtschaft" z 10 października $1918 \mathrm{r}$.

12 Tamże.

${ }^{13}$ A. Legu n-Biliński : Nasze projekty kanałowe, „Przegląd Techniczny” t. 45: 1927 nr 45 s. 968.

${ }^{14}$ J. B u n d: Rozwój kolejnictwa małopolskiego w okresie 80-lecia (1850-1930), działalności Krakowskiej Izby Przemysłowo-Handlowej oraz przebieg starań o wykonanie Ustawy Koerberowskiej o budowie dróg wodnych, Kraków 1930, s. 58-59.

15 Tamże. 
zadaniem rozbudowy własnych dróg wodnych stanęła odrodzona Rzeczpospolita. Wydaje się przy tym niemal pewne, że w poglądach na kierunki tej rozbudowy Polacy w dużym stopniu bazowali na koncepcjach powstałych przed rokiem 1918. Podejmowano wręcz realizację odziedziczonych po zaborcach projektów komunikacyjnych, powstałych przecież w innych uwarunkowaniach politycznych i gospodarczych. Tak było w przypadku portu na Wiśle w Płocku, którego budowę rozpoczęto już w styczniu 1919 r., ponieważ, jak dwa miesiące później, podczas 21 posiedzenia Sejmu wyjaśnił ówczesny minister robót publicznych Józef Pruchnik „znalazł się projekt dobrze opracowany przez Niemców"16. Takie uzasadnienie podjęcia tej inwestycji krytykował później m.in. inż. Antoni Legun-Biliński stwierdzając, że była to „kapitalna omyłka hydrotechniczna, wielka krzywda tak dla samej rzeki, jak również i dla interesów ekonomicznych m. Płocka"17. Według Legun-Bilińskiego port w tym mieście był oczywiście bardzo potrzebny, ale na prawym brzegu rzeki i dlatego jednak lepiej „trzeba było trzymać się nieco innej trasy, niż niemiecka”.

Nie mniej niż dostępność gotowych, choć nieprzystających do nowych uwarunkowań projektów kontynuacji koncepcji zaborczych decydował fakt, że w pierwszym okresie po odzyskaniu niepodległości zręby polskiej polityki w tej dziedzinie kładli inżynierowie hydrotechnicy, którzy wykształcenie i doświadczenie zawodowe zdobyli w niemieckiej, austrowęgierskiej i rosyjskiej służbie hydrotechnicznej. Nierzadko byli autorami projektów powstałych przed 1918 r., które teraz z mniej lub bardziej skrywanych pobudek osobistych promowali. W efekcie rozmach kreślonych wówczas planów rozbudowy sieci dróg wodnych często przekraczał możliwości (i potrzeby) młodego państwa, a pod względem kierunku prowadzenia niektóre z tych odziedziczonych po zaborcach projektów niekoniecznie odpowiadały jego interesom.

W takiej sytuacji potrzeba wypracowania spójnego, długofalowego programu rozwoju krajowych dróg wodnych stała się oczywistością. Pierwszą próbę jego naszkicowania podjęło Ministerstwo Robót Publicznych (MRP) już na wiosnę 1919 r., zaraz po tym, jak zostało powołane do życia. Resort ten, w rządzie Jędrzeja Moraczewskiego kierowany przez inż. Józefa Pruchnika, otrzymał bardzo szerokie uprawnienia - od budownictwa komunalnego i drogowego, poprzez sprawy osadnictwa aż po turystykę ${ }^{18}$. Dekret naczelnika państwa z 19 stycznia powołujący ten resort na pierwszym miejscu wymieniał jednak budownictwo wodne i - jeśli sądzić z zaangażowania Pruchnika, notabene hydrotechnika - to pierwszeństwo to nie ograni-

${ }^{16}$ Sprawozdanie stenograficzne z 21 posiedzenia Sejmu Ustawodawczego z dnia 29 marca 1919 r., s. XXI/41.

${ }^{17}$ A. Le gun - Biliń s ki : Nasze projekty... s. 968.

${ }^{18} \mathrm{Na}$ szerokie kompetencje zwraca uwagę m.in. Jacek Goclon tłumacząc to wielością problemów związanych z unifikacją ustrojową i ekonomiczną Polski porozbiorowej (zob. te g o ż : Ustrój Rady Ministrów, ministerstw i system kontroli resortowej w Polsce w latach 1918-1928, „Folia Iuridica Universitatis Wratislaviensis” t. 2: 2013 nr 1 s. 67. 
czało się jedynie do pozycji na liście kompetencji nowego organu. W myśl dekretu MRP miało zajmować się budową i utrzymaniem śródlądowych dróg wodnych oraz portów i przystani, budową zbiorników wodnych i wykorzystaniem wód w celach energetycznych, regulacją rzek i melioracją gruntów rolnych, a także miało nadzór nad funkcjonowaniem żeglugi śródlądowej.

Nowopowstały resort Pruchnika przejął również część kompetencji Ministerstwa Pracy i Opieki Społecznej, przede wszystkim tych dotyczących przeciwdziałania bezrobociu. Chodziło tu o ułatwienie angażowania bezrobotnych przy bardzo zwykle pracochłonnych robotach hydrotechnicznych i drogowych, rozwiązując w ten sposób dwa problemy jednocześnie: nadmiar rąk do pracy oraz brak dogodnych dróg komunikacyjnych. Choć taki zakres zadań ministerstwa wydawał się nie być pozbawiony sensu, w praktyce doprowadził jednak do sytuacji dość kuriozalnej. Otóż z jednej strony wypadało rozważnie przygotować projekt sieci dróg wodnych determinujących kierunki rozwoju gospodarczego kraju na lata, a z drugiej - przewidując przebieg konkretnych kanałów, trzeba było natychmiast wysyłać w teren tysiące bezrobotnych, byle tylko zaangażować ich do jakiejkolwiek pracy. Problem był na tyle pilny, że otwierając konsultacje nad pośpiesznie przygotowanym rządowym programem rozbudowy dróg wodnych, Pruchnik nie wspomniał nawet o kwestiach komunikacyjnych, ale mówił o „potrzebie śpiesznego podjęcia robót przy budowie dróg wodnych [...] ze względu na liczne rzesze bezrobotnych, zwłaszcza w okolicy Warszawy, Łodzi i zagłębia węglowego"19.

Konsultacjom tym Pruchnik nadał dobrze znaną sobie formułę tzw. ankiety zjazdu specjalnie zaproszonych specjalistów, którzy mieli wyrazić opinię na temat przedłożonego projektu. Zwoływanie takich ankiet było dość powszechnie praktykowane przez instytucje, magistraty czy towarzystwa techniczne w zaborze austriackim. Dyskutowano w ten sposób różne kwestie, od ocen przyczyn katastrof budowlanych i proponowanych zmian przepisów po wykonalność konkretnych przedsięwzięć inżynierskich.

Ankieta, zwołana do Warszawy początkowo na 18 marca 1919 r., została przełożona na późniejszy termin z „powodu trudności komunikacyjnych ze Lwowem”, jak eufemistycznie tamtejsza prasa określiła zajęcie przez Ukraińców linii kolejowych prowadzących do miasta ${ }^{20}$. Zanim wyznaczono kolejny termin, 12 marca pracownicy ministerstwa referowali na temat założeń rządowej koncepcji w siedzibie Stowarzyszenia Techników Polskich (STP) w Warszawie. Tadeusz Tillinger mówił wtedy o ujętych w programie kanałach, natomiast Alfred Konopka - o uspławnieniu Wisły. W siedzibie STP na ul. Czackiego wystąpił ponadto Adam Różański z referatem o zbiornikach wodnych w dorzeczu Wisły. W dyskusji, jaka wywiązała się po tych prezentacjach, głos zabierali m.in. Roman Ingarden i Mateusz Puciata ${ }^{21}$.

\footnotetext{
${ }^{19}$ Ankieta w sprawie budowy dróg wodnych, „Roboty Publiczne” t. 1:1919 z. 2 s. 16.

20 "Gazeta Lwowska” t. 109:1919 nr 70.

${ }^{21}$ Budowa dróg wodnych w Polsce, „Roboty Publiczne” t. 1: 1919 z. 1 s. 26.
} 


\section{DROGI WODNE W POLSCE}

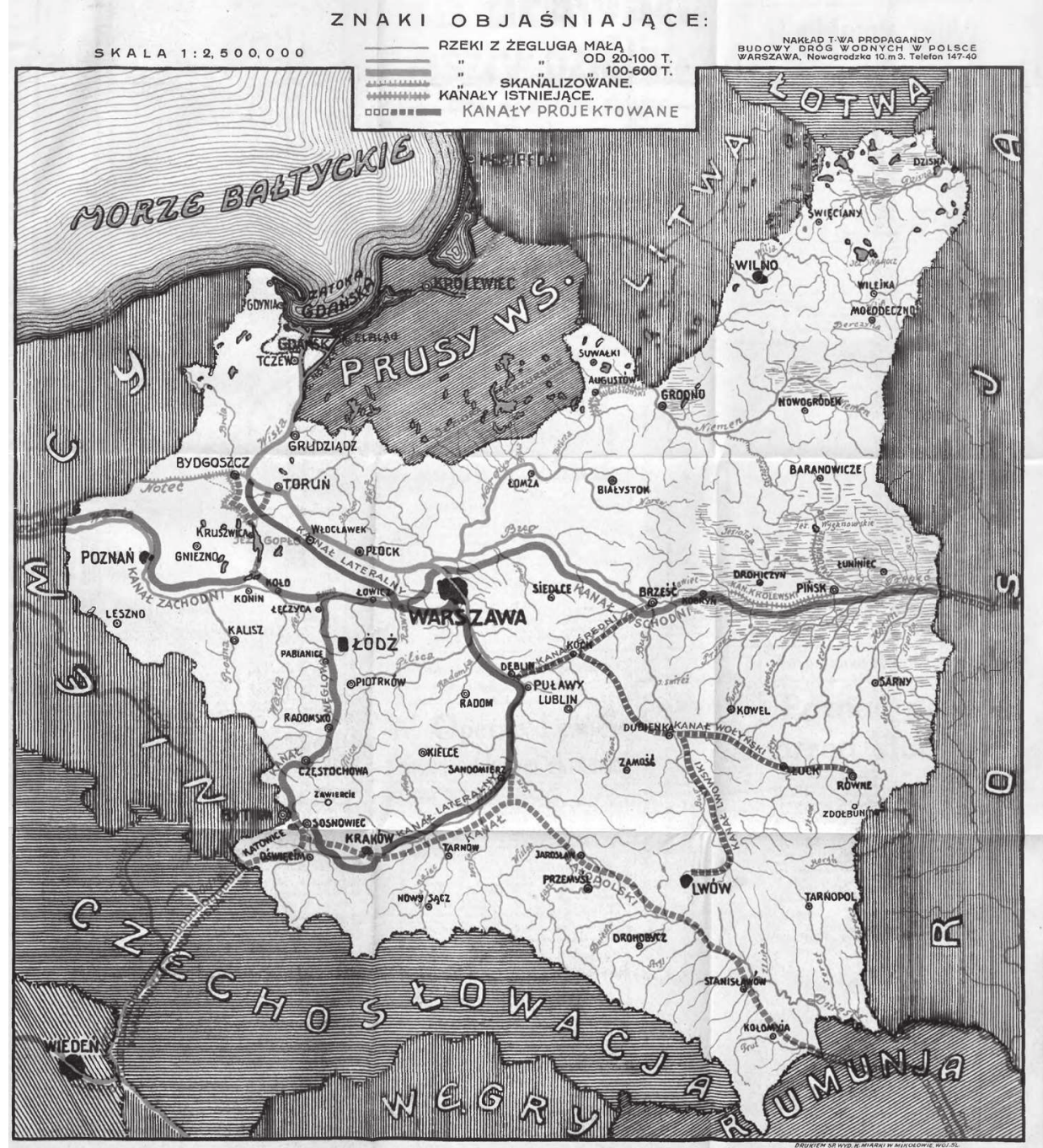

KIERUNK! KANATÓW PROJEKTOWANYCH PRZEZ INŻ, KAROLA PESZKOWSKIEGO

Ryc. 1. Sieć głównych krajowych szlaków żeglugowych projektowanych przez Towarzystwo Propagandy Budowy Dróg Wodnych w Polsce (K. Peszkowski: Drogi Wodne w Polsce. Tom V. Problem Drogi Wodnej z Górnego Śląska. Warszawa 1928). 
Dwa tygodnie później, na 21. posiedzeniu Sejmu, Pruchnik prezentował opracowane w swoim ministerstwie założenia programu budowy dróg wodnych, zapowiadając, że po zatwierdzeniu go przez Radę Ministrów zostanie wniesiony w formie projektu ustawy pod głosowanie w parlamencie. Zastrzegając, że choć realizacja takiego programu trwałaby wiele lat, minister podkreślał, że warto „mieć ten program na oku, bo trzeba o tych sprawach mówić, potrzeba społeczeństwo zainteresować, potrzeba ten program wystawić na najbardziej rzeczową krytykę tak, ażeby pod tym względem zrobić rzecz doskonałą"22. Przyznał, że w trakcie dotychczasowych konsultacji niejednokrotnie słyszał od rzeczoznawców, że zarówno kanał Śląsk-Bałtyk, jak i droga wodna Warta-Prypeć nie były koncepcjami nowymi, ale przyjmował te głosy „jako najlepszy komplement”, utwierdzały go bowiem w przekonaniu, że realizacja tych koncepcji była „postulatem wszystkich kół fachowych, ekonomicznych i obywatelskich w kraju"23.

Ostatecznie po uspokojeniu się sytuacji wokół Lwowa nowy termin zjazdu wyznaczono na 8 kwietnia. W warszawskiej siedzibie ministerstwa stawili się wówczas zaproszeni przedstawiciele środowiska naukowego, inżynierowie, przemysłowcy i samorządowcy z kilku głównych ośrodków w kraju: z Warszawy - prof. Aleksander Wasiutyński (Politechnika Warszawska), inżynierowie Antoni Ponikowski i Aleksander Sadkowski; z Krakowa - prof. Tadeusz Sikorski (Uniwersytet Jagielloński), prof. Maksymilian Matakiewicz i dr Karol Pomianowski (obaj z Politechniki Lwowskiej), inżynierowie Roman Ingarden i Andrzej Kędzior (będący równocześnie posłem z ramienia PSL „Piast”). Stawili się także przedstawiciele ważniejszych stowarzyszeń technicznych i kilku ministerstw oraz reprezentanci władz miejskich Warszawy, Łodzi i Poznania. Ze strony MRP oprócz Pruchnika uczestniczyło pięciu podlegających mu inżynierów, naczelników wydziałów i referenci - Tadeusz Tillinger, Józef Ćwikiel, Stanisław Chowaniec, Aleksander Różankowski oraz Adam Różański.

Zanim ten ostatni, jako prowadzący spotkanie, rozpoczął dyskusję nad pytaniami zawartymi w rozesłanym wcześniej kwestionariuszu, Tillinger przedstawił uczestnikom założenia programu rządowego, znane już zapewne tym, którzy - jak na przykład Ingarden - brali udział w marcowej konferencji w siedzibie STP. Projekt zakładał stworzenie dwóch wielkich arterii komunikacyjnych, „przeżynających” Polskę z południa na północ i z zachodu na wschód, tworząc tym samym tzw. „wielki krzyż” o ramionach przecinających się w rejonie Łowicza. Oś południe-północ miała łączyć śląskie zagłębie węglowe poprzez Częstochowę i okolice Łodzi z Wisłą powyżej Płocka, natomiast arteria zachód-wschód miała połączyć Wartę z Prypecią, biegnąc przez Warszawę.

Uzasadniając taki układ dróg, Tillinger wskazywał, że połączenie ze Śląskiem ułatwi transport wydobywanego tam węgla do odbiorców krajowych oraz -

${ }^{22}$ Sprawozdanie stenograficzne z 21 posiedzenia... s. XXI/41.

${ }^{23}$ Tamże. 
poprzez polski, jak wówczas sądzono, Gdańsk - na eksport. Z kolei połączenie Warta-Prypeć miało stać się „ogniwem [...] wielkiej wewnętrznej drogi wodnej Europejskiej od Renu (Mittelland Kanał) aż do ujścia Dniepru"24. Jego zdaniem, droga ta otwierała także przed polskim przemysłem duże szanse rozwoju - szczególnie miał na myśli dostęp do poleskiego drewna i ułatwienie dostaw ukraińskiej rudy żelaza. Kolejne dwie drogi, choć krótsze, w istotny sposób uzupełniały projektowany „krzyż”, stanowiąc przedłużenie jego osi południkowej. Był to kanał z Zagłębia Dąbrowskiego do Krakowa wraz z odnogą z Oświęcimia do Zagłębia Cieszyńskiego oraz projektowane skanalizowanie Wisły od Warszawy do Gdańska.

Rządowy plan obejmował również regulację Wisły od Warszawy do Krakowa oraz budowę zaprojektowanego jeszcze przed wojną tzw. kanału galicyjskiego, łączącego Wisłę z Dniestrem wraz z odnogą do Lwowa i dalej do Bugu. Projektowane drogi miały być przystosowane do ruchu jednostek o ładowności 1000 ton, co Tillinger uzasadniał doświadczeniem niemieckim i rosyjskim, gdzie - odpowiednio po Renie i Wołdze - pływały jednostki o wyporności nawet dwu- i trzy razu większej25. Ministerstwo przewidywało ponadto, że po upływie około 20 lat - na tyle szacowano czas realizacji programu - przepustowość dróg przystosowanych do żeglugi jednostek 600-tonowych okaże się niewystarczająca, w czym znowu powoływało się na doświadczenie niemieckie.

Poddając pod ocenę ekspertów ogólny schemat sieci, wspomniany „wielki krzyż” kanałów, ministerstwo chciało wiedzieć, czy ich zdaniem obie projektowane osie dróg wodnych były „właściwe i wskazane ze stanowiska gospodarstwa krajowego”26. 0 ile plany budowy osi południe-północ i regulacji Wisły nie budziły większych kontrowersji, w toku dyskusji praktycznie wszyscy uczestnicy zjazdu wypowiedzieli się przeciw budowie arterii zachód-wschód. Choć wskazywano na niecelowość takiego rozwiązania (np. Kędzior nie widział sensu łączenia rzek, które były ,jeszcze mało spławne”), to dominowały jednak argumenty natury politycznej. Ingarden na przykład uznawał taką inwestycję wprost za „szkodliwą” dla Polski. Powstałoby w ten sposób połączenie tranzytowe z Niemiec do Rosji, co - jego zdaniem - nie leżało w interesie Rzeczpospolitej. Przewidywał poza tym, że budowa takiej drogi nastręczyłaby wielu trudności natury technicznej i powątpiewał, by wpływy z opłat tranzytowych pokryły koszty jej utrzymania, co jego zdaniem „byłoby klęską dla całego kraju”27.

Inaczej polityczny kontekst tego zagadnienia interpretował inż. Suchorzewski, reprezentujący na spotkaniu Ministerstwo Przemysłu i Handlu. Jego zdaniem „W niedalekiej nawet przyszłości będzie wskazane rozpoczęcie budowy drogi wodnej Warta-Wisła-Dniepr" jako ruchu wyprzedzającego ewentualną realiza-

\footnotetext{
${ }^{24}$ T. Till in ge r: Sztuczne drogi wodne, „Roboty Publiczne” t. 1:1919 z. 1 s. 31.

${ }^{25}$ Tamże s. 28 i 32

${ }^{26}$ Ankieta w sprawie... s. 16.

${ }^{27}$ Tamże s. 17-18.
} 
cję istniejących już rosyjsko-niemieckich planów połączenia Dźwiny Zachodniej z Dnieprem, co umożliwiłoby obu krajom rozwijanie wzajemnych kontaktów handlowych z pominięciem polskiego terytorium ${ }^{28}$. Najwyraźniej to, co zdaniem jednych było zagrożeniem, dla innych jawiło się jako szansa na wykorzystanie geopolitycznego położenia kraju.

Uczestnicy zjazdu mieli odpowiedzieć także na pytanie, czy założony w rządowym projekcie standard dróg, przystosowanych do żeglugi jednostek o wyporności do 1000 ton, był odpowiedni dla polskich potrzeb, a jeśli nie, to jaki wariant należałoby przyjąć. Zdaniem większości uczestników ankiety wystarczyłoby zapewnienie przepływu jednostkom do 600 ton. Chodziło przede wszystkim o to, by taka standardowa jednostka miała dostęp do większości dróg wodnych w kraju. Gdyby przyjęto wariant 1000 ton, poza zasięgiem takich statków znalazłyby się nieuregulowane odcinki Wisły, Bugu i Narwi. Za wyborem mniejszej wyporności opowiadali się przede wszystkim inżynierowie krakowscy i lwowscy, przypominając, że w wyniku długich studiów taki właśnie standard przyjęto dla kanału galicyjskiego ${ }^{29}$.

Tillinger dowodził jednak, że podejmując tak poważną inwestycję warto ponieść nieco większy koszt (ok. 20\%), aby znacznie zwiększyć przepustowość drogi wodnej. Założonewrządowym projekcieprzekrojepoprzecznekanałów dlastatków600 i 1000 ton niewiele się w zasadzie różniły: przy jednakowej szerokości dna, szerokość zwierciadła wody wynosiła odpowiednio 29,4 i 33 m, natomiast głębokość w przekopach 3 i 3,5 $\mathrm{m}^{30}$. Taki argument przemawiał do Sadkowskiego i Kędziora, a Pawłowicz z kolei uważał, że w dłuższej perspektywie droga 1000-tonowa lepiej służyłaby polskim interesom ułatwiając import surowców z Rosji. Logicznym wydawało się też projektowanie śluz odpowiednich dla większych barek, co w minimalnym stopniu zwiększało koszt inwestycji, ale otwierało możliwość łatwego podniesienia tonażu drogi wodnej w przyszłości. Ostatecznie, o ile w kwestii zasadniczych kierunków budowy dróg wodnych w Polsce obrady przyniosły pewne rozstrzygnięcia (przede wszystkim zrezygnowano z połączenia Warta-Prypeć), to w sprawie wyboru tonażu nie osiągnięto kompromisu i zdecydowano kontynuować tę dyskusję podczas kolejnych posiedzeń ankiety ${ }^{31}$.

19 kwietnia, nieco ponad tydzień po zakończeniu konsultacji, rządowy program został złożonych do laski marszałkowskiej w formie projektu dwóch ustaw, skierowanych następnie do połączonych Komisji Robót Publicznych i Wodnej. Pierwsza z proponowanych ustaw miała upoważniać rząd do „urządzenia względnie ulepszenia" dziesięciu dróg wodnych - budowy pięciu kanałów i regulacji tyluż rzek - oraz przyznania, jeszcze w roku 1919, jednego miliona marek polskich na niezbędne stu-

\footnotetext{
${ }^{28}$ Tamże s. 26.

${ }^{29}$ Tamże s. 21.

${ }^{30}$ Tamże s. 22.

${ }^{31}$ Brak jest informacji, czy takie posiedzenie w ogóle się odbyło.
} 
dia przygotowawcze i opracowanie projektów technicznych. W drugiej ustawie rząd domagał się przyznania na ten sam rok kredytu w wysokości 50 milionów marek na podjęcie natychmiastowych robót w terenie ${ }^{32}$. A zatem, oprócz uregulowania Wisły, Sanu, Bugu, Narwi i Warty, chodziło o budowę kanałów: Warszawa-Bug (tzw. Żerańskiego), Lwów-Bug, Odra-Wisła-Dniestr, Śląsk-Warszawa oraz łącznika pomiędzy tym ostatnim a kanałem Śląsk-Kraków, rozpoczynającym swój bieg w Oświęcimiu.

Oczywiście Pruchnik nie miał na myśli jednoczesnego rozpoczynania wszystkich inwestycji, niemniej połączone komisje zasugerowały sprecyzowanie zadań, których realizacja zostałaby podjęta w pierwszej kolejności. Uznano, że wysiłek ministerstwa powinien skoncentrować się na regulacji Wisły oraz na dwóch kanałach - Warszawa-Bug i Kraków-Oświęcim (którego budowę rozpoczęły jeszcze władze austrowęgierskie). Poza tym zobowiązano ministerstwo do rozpoczęcia prac przy budowie zbiornika wodnego na Sole w Porąbce ${ }^{33}$. Co się tyczy pieniędzy przeznaczonych na badania, komisje obniżyły ostatecznie ich kwotę o połowę, na co minister bez oporów przystał, stwierdzając, że i tak „rząd więcej absolutnie wydać nie może, ponieważ pół roku już minęło" ${ }^{34}$.

Uzgodniony w komisjach projekt ustawy obejmującej oba wnioski ministerialne wszedł pod obrady Sejmu podczas jego 66 posiedzenia, 9 lipca 1919 r. Przedłożenie rządowe referował nie kto inny, jak poseł Andrzej Kędzior, aktywnie uczestniczący w kwietniowej ankiecie. Co charakterystyczne, przestawiając rządowy program, więcej uwagi niż owym dziesięciu projektom poseł sprawozdawca poświęcił „kanałowi europejskiemu", a właściwie tłumaczeniu powodów, dla których z niego zrezygnowano. Wyjaśniał, że przystępując do tej inwestycji, oprócz z Niemcami na zachodzie Polska musiałaby się „porozumieć nie wiadomo z kim na wschodzie”, a wobec wciąż napiętej sytuacji w Rosji Sowieckiej stan taki mógł trwać dość długo ${ }^{35}$. Poza tym Kędzior powtórzył pogląd wyrażany niejednokrotnie podczas ankiety (głównie przez Ingardena), że „kanał ten leżałby więcej w interesie Niemiec [...] a dla Polski nie miałby takiej wartości i takiego znaczenia"36. Poseł wyjaśniał, że połączone komisje za najważniejsze uznały te roboty, które leżały w interesie kraju, choć zarazem stwierdził, że gdyby stosowne traktaty z sąsiadami były podpisane, to budowa tej drogi wodnej znalazłaby się na pierwszym miejscu priorytetów rządu ${ }^{37}$.

32 Ministerstwo Robót Publicznych do Marszałka Sejmu Ustawodawczego RP, Druk nr 404, Zał. 2, 19 kwietnia $1919 \mathrm{r}$.

${ }^{33}$ Sejm Ustawodawczy Rzeczypospolitej Polskiej: Sprawozdanie połączonych komisji robót publicznych i wodnej o przedłożeniu Rządu w przedmiocie budowy dróg wodnych, 1919, Druk nr 639, s. 7.

${ }^{34}$ Sprawozdaniestenograficzne z 66 posiedzenia Sejmu Ustawodawczego z dnia 9 lipca 1919 r., s. LXVI/29

${ }^{35}$ Tamże s. LXVI/28

${ }^{36}$ Tamże.

${ }^{37}$ Tamże s. LXVI/36. 
Pewne zastrzeżenia posłowie zgłaszali wobec określonej w projekcie ustawy kolejności robót. Reprezentujący PSL „Wyzwolenie”, znany z radykalnych poglądów społecznych ksiądz z Podkarpacia, Eugeniusz Okoń (1881-1949) narzekał, że na liście priorytetów nie znalazł się kanał Wisła-Dniestr, którego projekt przygotowano jeszcze przed wojną. Z kolei poseł Związku Ludowo-Narodowego, inż. Aleksander de Rosset (1866-1933) uważał, że najpierw - i to niemal natychmiast - należałoby podjąć prace przy budowie kanału Śląsk-Warszawa, który „przechodzi przez kraj, gdzie właśnie jest najwięcej rąk roboczych z jednej strony, a z drugiej gdzie chodzi o masowy przewóz węgla"38. Pruchnik odparł jednak na to, że zanim rozpocznie się prace budowlane należy najpierw dogłębnie przeanalizować kwestię zaopatrzenia kanału w wodę i zweryfikować, czy wszystko „będzie należycie fungować”39. Co charakterystyczne, nikt nie kwestionował zasadności umieszczenia na ministerialnej liście kanału Lwów-Bug, o którym sam poseł-sprawozdawca wprost mówił jako „niemożliwym do wykonania, dlatego że na działach szczytowych pod Lwowem nie ma wody" do jego zasilania ${ }^{40}$.

Odpowiadając dalej Rossetowi, Pruchnik zwrócił uwagę na i tak szybkie tempo prac przygotowawczych wykonanych przez jego resort. Przecież od powstania ministerstwa do opracowania programu minęło zaledwie kilka miesięcy - argumentował odpierając zarzut, że przygotowując ten program nie uwzględniono kwestii społecznych mówił, że była to „praca więcej, niż amerykańska, pod wpływem tej psychozy, żeby w tej chwili otworzyć roboty dla zajęcia bezrobotnych"41. Ostatecznie jednak, bez żadnych poprawek ustawa została jednogłośnie przyjęta tego samego dnia ${ }^{42}$. Odtąd budowa dróg wodnych stała się nie tylko obowiązkiem rządu, lecz też jego wyłączną prerogatywą.

\section{Założenia a praktyka}

Zadekretowanie rządowego programu budowy dróg wodnych w formie ustawy, choć dawało MRP podstawę prawną do działania oraz - przynajmniej teoretycznie - zabezpieczało znaczne środki finansowe na jego realizację, bynajmniej nie rozwiązywało sprawy ani nawet nie zamykało dyskusji nad kierunkami rozwoju żeglugi śródlądowej w Polsce. Przeciwnie - różnica stanowisk, jaka podczas kwietniowej ankiety zarysowała się pomiędzy różnymi środowiskami inżynierskimi, gospodarczymi i politycznymi utrwaliła się, a spór o przyszły kształt krajowej sieci dróg wodnych trwał z różną intensywnością do końca okresu międzywojennego; albowiem

\footnotetext{
${ }^{38}$ Tamże s. LXVI/32.

${ }^{39}$ Tamże s. LXVI/34.

${ }^{40}$ Tamże s. LXVI/28.

${ }^{41}$ Tamże s. LXVI/34.

${ }^{42}$ Ustawa z dnia 9 lipca 1919 roku o budowie kanałów żeglownych, tudzież regulacji rzek żeglownych i spławnych, Dz.Pr.P.P. 1919 nr 59 poz. 356.
} 
do wybuchu drugiej wojny światowej o polskich drogach wodnych głównie dyskutowano. Nadal spierano się nie tylko o kierunki prowadzenia głównych arterii, lecz także o tonaż statków, które miały po nich kursować.

Z pewnym przybliżeniem można przyjąć, że zasadnicza różnica poglądów co do przyszłości polskiej sieci kanałów, przebiegała po linii dawnych podziałów rozbiorowych, wciąż jeszcze żywych w dopiero co odrodzonej Rzeczpospolitej. Ta różnica poglądów wynikała po części zapewne z odmiennych doświadczeń zawodowych, jakie stały się udziałem inżynierów pracujących uprzednio w służbach hydrotechnicznych państw zaborczych, przede wszystkim Rosji i Austro-Węgier, ale nie mniej ważne były względy ambicjonalne zarówno całych środowisk jak i osobiste animozje pomiędzy poszczególnymi inżynierami, a szczególnie pomiędzy Romanem Ingardenem a Tadeuszem Tillingerem. Konflikt między nimi nie ograniczał się już tylko do krytyki kompetencji zawodowych, każących podejmować te czy inne decyzje w zakresie rozwiązań technicznych, lecz dotykał także sprawy ewentualnych motywacji politycznych, jakie za tymi decyzjami stały.

Odnosząc się do wyjaśnień Tillingera, że arterię przez Polesie rozważano już wcześniej, Ingarden wyrażał zdziwienie, ,jak można argumenta, które skłaniały rząd niemiecki i ukraiński do projektowania [...] drogi wodnej między Wartą a Prypecią, przytaczać jako uzasadnienie, i to najważniejsze, wybudowania tej drogi wodnej przez rząd polski" ${ }^{43}$. Ingarden oczywiście wiedział, skąd u Tillingera zarówno znajomość, jak i zrozumienie tych argumentów - w czerwcu 1918 r. wszedł on bowiem w skład komisji powołanej przez ówczesnego premiera Ukraińskiej Republiki Ludowej hetmana Pawło Skoropadskiego w celu przygotowania tej inwestycji. Do komisji tej rząd ukraiński chciał dokooptować również przedstawicieli Niemiec oraz Polski, i w tym celu wysłał Tillingera oraz polskiego inżyniera, Jaworskiego, do Królestwa na rozmowy w tej sprawie. Ostatecznie nie doszło do nich, ponieważ - jak wyjaśniał Tillinger - rząd w Berlinie, „zaznaczając przychylność do idei budowy kanału, na przyjazd delegacji do Warszawy nie zezwolił, uznając udział Polski w tej sprawie za przedwczesny"44. Ingarden zdawał się mieć za złe Tillingerowi jego ówczesną postawę i wprost wytykał jemu oraz Jaworskiemu, że ,jako delegatom tak ściśle z Niemcami zaprzyjaźnionego rządu ukraińskiego” pozwolono im nawet zwiedzić niemieckie „roboty kanałowe”45.

Zaangażowanie Tillingera w ideę budowy drogi wodnej przez Polesie było logiczną konsekwencją jego wcześniejszych prac nad projektem połączenia Bałtyku z Morzem Czarnym. Już w 1908 r. w wydanej w Petersburgu broszurze zaproponował budowę arterii Dniepr-Prypeć-Wisła łączącej Chersoń z Gdańskiem dowodząc, że taka

${ }^{43}$ R. Ingarden: Skutek gospodarczy projektowanych $w$ Królestwie Kongresowem kanałów żeglownych, Kraków 1920, s. 44-45.

${ }^{44}$ T. Tilling er: Sztuczne drogi... s. 35.

${ }^{45}$ R. I n gar d e n : Skutek gospodarczy... s. 44. Później zarzuty te powtórzył Antoni Legun-Biliński (zob. tegoż: Nasze projekty... s. 968). 
trasa byłaby dogodniejsza niż zaprojektowane w 1905 r. połączenie Chersonia z Rygą za pośrednictwem Dniepru i Dźwiny Zachodniej ${ }^{46}$. Jako że droga miała służyć przede wszystkim do przeprowadzania jednostek floty bałtyckiej i czarnomorskiej pomiędzy obydwoma akwenami, wymiary kanału miały być wprost gigantyczne - jego głębokość na całej długości miała wynosić ok. 10 m, co czyniłoby taką drogę wodną dostępną również dla pełnomorskich statków handlowych. Rozmach przyjętych wówczas założeń wydaje się po części tłumaczyć późniejszą determinację Tillingera, by i na polskie potrzeby projektować na tej trasie kanały o parametrach odpowiednich dla dużych jednostek. Jego zdaniem, skoro drogi wodne za wschodnią granicą budowano dla statków o ładowności 1700 ton, to dla dróg polskich wymiar 1000 ton stanowił absolutne minimum ${ }^{47}$.

W toku dyskusji toczącej się w kręgach inżynierskich na ten temat Tillinger starał się odpierać zarzuty o rzekomych zagrożeniach, jakie realizacja tej inwestycji miała przynieść Polsce. W 1924 r., odpowiadając na krytykę ze strony „nestora krakowskich hydrotechników” (jak nazywał Ingardena), zapytywał retorycznie

co byłoby korzystniejsze dla narodu zajmującego środek kontynentu: czy starać się ułatwić tranzyt przez swoje terytorium i stać się łącznikiem handlowym pomiędzy

Wschodem i Zachodem, czy zaporą? Mostem czy ścianą? ${ }^{48}$

Dowodził, że jeśli Polska wybrałaby to drugie, to Niemcy i tak wytyczyłyby inne szlaki handlowe z Rosją - drogę morską, kanał Ren-Dunaj lub nawet kanał Dniepr-Dźwina. To ostatnie połączenie, wówczas ciągle w fazie wstępnej koncepcji, wobec ewentualnego blokowania przez Polskę budowy drogi wodnej przez Polesie, mogłoby zyskać na atrakcyjności. „Dla Niemiec różnica będzie niezbyt wielka, stracimy tylko my" - przekonywał Tillinger ${ }^{49}$.

Z podobną determinacją bronił proponowanych dla tej drogi parametrów technicznych i wyliczeń uzasadniających spodziewane efekty ekonomiczne inwestycji, choć z czasem gargantuiczna wizja kanału dla statków 1700 czy 1000 tonowych, biegnącego na południe od starego Kanału Królewskiego, ustąpiła bardziej realistycznej koncepcji modernizacji istniejącej drogi wodnej. Nowy, skromniejszy plan opracowany w MRP w 1924 r. przewidywał otwarcie tej drogi dla jednostek 400-tonowych, co zasadniczo spełniało wcześniejsze postulaty Ingardena. Według tego nowego, skromniejszego wariantu tor wodny miał być pogłębiony do 2,5 metra,

${ }^{46}$ T. Tilling er: Baltiysko-Chernomorskiy morskoy kanal, Sankt-Peterburg 1908. Obszerne streszczenie tej pracy zamieścił A. Sadkowski: Kanał Bałtycko-Czarnomorski, „Przegląd Techniczny" t. 46: 1908 nr 11 s. 136. Niewiele wiadomo o tym okresie życia Tillingera. Jak wynika z jego nekrologu, w latach 1914-1918 pełnił funkcje naczelnika robót drogowych przy dowództwie jednej z armii rosyjskich, a do Polski wrócił dopiero w 1919 r.

${ }^{47}$ T. Tilling e r: Sztuczne drogi... s. 32

${ }^{48}$ T.Tilling er: Drogawodnatranseuropejska(cz.II),,,Przegląd Techniczny” t.62:1924 nr 19 s. 214.

${ }^{49}$ Tamże. 
a kanały poszerzone w koronie do $26 \mathrm{~m} \mathrm{z}$ możliwością powiększenia do $34 \mathrm{~m}$, gdyby w przyszłości wzrost potrzeb przewozowych wymusił konieczność przystosowania kanału do ruchu jednostek 1000-tonowych. Poza tym zakładano sprostowanie części koryta Muchawca i Piny pomiędzy Brześciem a Pińskiem oraz zastąpienie 20 starych i nieefektywnych jazów iglicowych 5 śluzami komorowymi o spadku 4 metrów każda.

Zdaniem Tillingera modernizacja drogi wodnej Brześć-Pińsk, dzięki dogodnym warunkom terenowym, a także z uwzględnieniem wcześniej wykonanych na tej trasie prac kosztowałaby znacznie mniej niż budowa linii kolejowej. Ponadto w tym wariancie w porównaniu z budową nowego kanału odpadałaby konieczność wywłaszczenia terenów, budowy mostów i urządzeń zasilających kanał w wodę ${ }^{50}$. Ponieważ starym Kanałem Królewskim spławiano w najlepszym przypadku barki 100-tonowe, przystosowanie tej drogi dla jednostek 400-tonowych i tak stanowiłoby znaczącą poprawę. W praktyce transeuropejska droga wodna przez Polesie stałaby się faktem.

\section{Kanał węglowy a droga wodna Zachód-Wschód}

Po tym, jak przyjęta w lipcu 1919 r. ustawa odłożyła kwestię budowy drogi Zachód-Wschód na bliżej nieokreśloną przyszłość, dalsze zabiegi o realizację polskiego odcinka tej transeuropejskiej arterii wodnej i spór o jej parametry mogły wydawać się daremne. A jednak kierunek ten wciąż był ważny w perspektywicznych planach rozwoju polskiej żeglugi śródlądowej i choć spadł z listy priorytetów rządu, zaczął się nim interesować kapitał prywatny oraz samorządy. Problemem było jednak prawo, zgodnie bowiem ze wspomnianą ustawą sprawy regulacji rzek i budowy kanałów żeglownych stały się wyłączną domeną władz centralnych.

Za zmianą przepisów usilnie lobowały osobistości sfer politycznych, wojskowych, finansowych i technicznych II Rzeczpospolitej - dość wymienić marszałka Senatu Wojciecha Trąmpczyńskiego (1860-1953) czy inż. gen. Józefa Lipkowskiego (1863-1949). Ten ostatni wspólnie z Tillingerem firmował działalność Syndykatu Bałtyk-Morze Czarne, organizacji aktywnie działającej przynajmniej od lata 1921 r., kiedy to podjęto pierwszą próbę jej rejestracji ${ }^{51}$. Pierwszym przedsięwzięciem, które Syndykat zamierzał podjąć, było powołanie Towarzystwa Akcyjnego „Kanał Węglowy Śląsk-Gdańsk" stawiającego sobie za cel budowę tego właśnie, południkowego ramienia „wielkiego krzyża” kanałów zaprojektowanego przez Tillingera.

Był to praktycznie ten sam projekt, który prezentowany był dwa lata wcześniej jako podstawa programu rządowego. Każe to zadać pytanie, na ile powstanie Syndy-

50 Tamże s. 212.

${ }^{51}$ Ostatecznie, syndykat został zarejestrowany dopiero 14 stycznia 1925 r. Zob. Dziennik urzędowy Ministerstwa spraw wewnętrznych, 1925, poz. 161, s. 33. 
katu było reakcją inicjatywy prywatnej na bezczynność rządu, a na ile było to narzędzie w ręku władz państwowych stwarzające jedynie pozory niezależności. Trudno jednoznacznie ustalić autorstwo tego projektu, ale jeśli nawet wyszedł on w całości spod ręki Tillingera, stało się to w okresie, gdy kierował w Ministerstwie Robót Publicznych sprawami sztucznych dróg wodnych. Wprawdzie wykreślona na mapie w wielkiej skali koncepcja sieci komunikacyjnej to nie opis patentowy czy innego rodzaju utwór autorski, do którego prawo przechodzi zwykle z autora na pracodawcę, to jednak dość zastanawiające jest, z jaką swobodą Tillinger, wciąż pozostając pracownikiem ministerstwa, mógł wnieść ten projekt w poczet prywatnego - było nie było - przedsięwzięcia, jakim był Syndykat Bałtyk-Morze Czarne.

W prospekcie załączonym do wniosku o rejestrację tego przedsiębiorstwa (a załączonym jako bezpłatny dodatek do Przeglądu Technicznego w sierpniu 1921 r.) Tillinger i Lipkowski deklarowali, że tuż po jego wykonaniu Syndykat przystąpi do budowy arterii Zachód-Wschód, „łączącej Wisłę przez Bug i Prypeć z dorzeczem Dniepru, Ukrainę i Południową Rosję, z jej bogactwami mineralnymi”, a także zaprojektowanego jeszcze przed pierwszą wojną światową kanału galicyjskiego, „mającego połączyć Wschodnią Małopolskę i zagłębie naftowe ze Śląskiem i Bałtykiem, a przez Dniestr z Rumunią i Morzem Czarnem"52.

Drugą organizacją propagującą ideę rozbudowy w Polsce sieci dróg wodnych i zabiegającą o zmianę przepisów dających państwu monopol w tej dziedzinie było Towarzystwa Propagandy Budowy Dróg i Budowli Wodnych w Polsce oraz ich Uprzemysłowienia i Wykorzystania. Jego honorowym przewodniczącym był marszałek Trąmpczyński, dyrektorem generalnym - inż. Rafał Mierzyński, a w skład zarządu wchodziło wielu przedstawicieli samorządów. To właśnie samorządy, zgodnie z koncepcją lansowaną przez Towarzystwo, miały przejąć od państwa odpowiedzialność za inicjatywę budowy i utrzymania dróg wodnych. Choć Towarzystwo aktywnie popularyzowało swoje koncepcje od zjazdu założycielskiego w Kruszwicy w 1920 r., zostało formalnie zarejestrowane dopiero 31 lipca 1923 r. Od tego momentu podjęło jeszcze bardziej intensywną agitację przede wszystkim wśród samorządów potencjalnie najbardziej zainteresowanych rozwojem żeglugi śródlądowej, a zatem lokalnych władz na Śląsku oraz w miastach leżących na trasie lub chociażby w strefie oddziaływania projektowanych arterii ${ }^{53}$.

W dużym stopniu pod naciskiem obu organizacji - a raczej ich wpływowych członków - latem 1923 r. rozpoczęto prace nad nowelizacją ustawy ${ }^{54}$. Ostatecznie nowe prawo weszło w życie w końcu lipca następnego roku. Na mocy tej nowelizacji

\footnotetext{
${ }^{52} \mathrm{~J}$. L i p k o w s k i, T. Till in ge r: Memorjał finansowy, techniczny i ekonomiczny dołączony do podania o zatwierdzenie Statutów Spółki Akcyjnej „Kanał Węglowy Śląsk-Gdańsk” z odnogami do Warszawy i do Poznania, Warszawa 1921, s. 7-8.

${ }^{53}$ Dziennik urzędowy Ministerstwa spraw wewnętrznych, 1923, poz. 158, s. 20.

${ }^{54}$ Budowa kanału węglowego. Wobec nowego projektu ustawy o budowie i koncesjonowaniu dróg wodnych, „Republika” t. 1:1923 nr 212.
} 


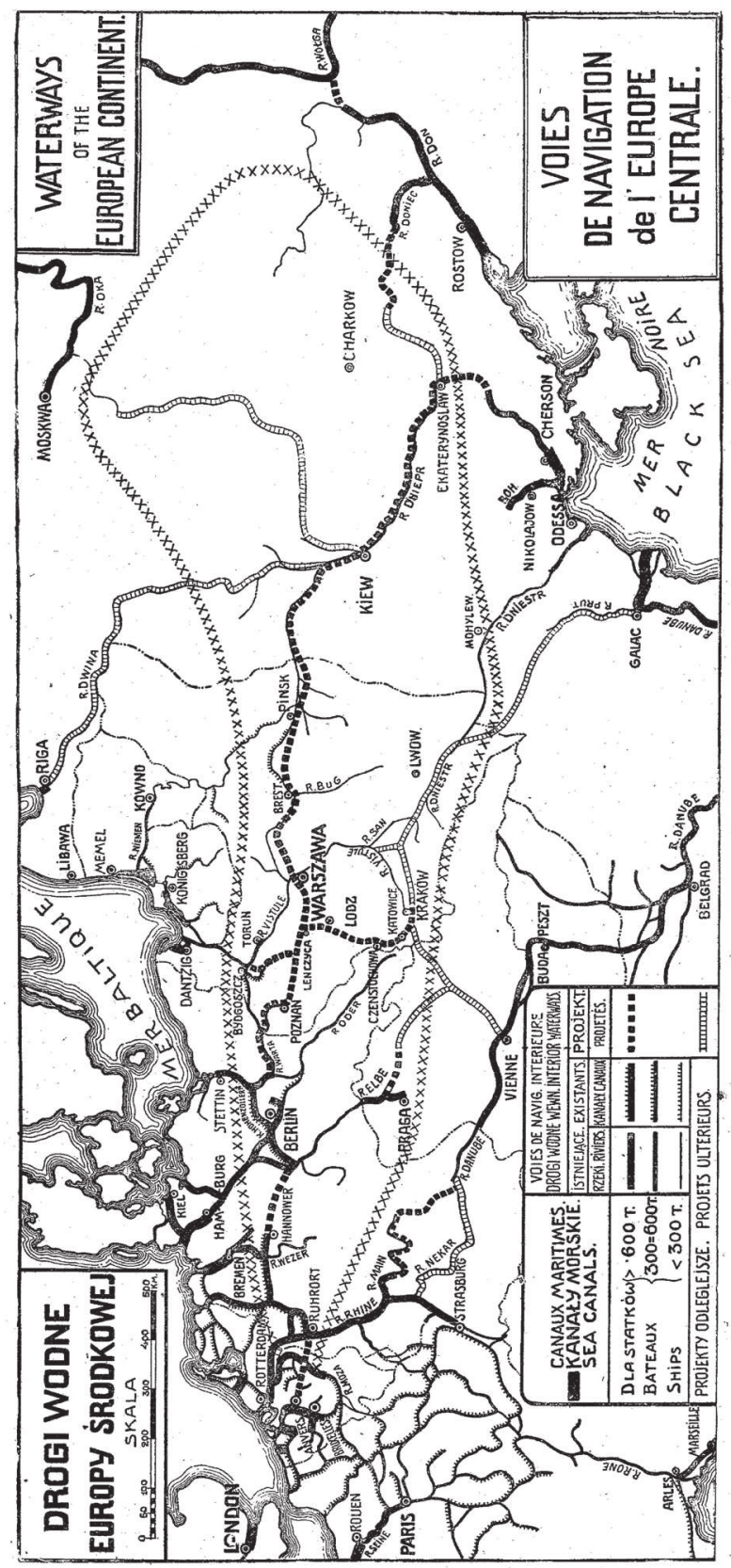

Ryc. 2. Obszar ciążenia do transeuropejskiej drogi wodnej określony dla Rotterdamu jako portu docelowego. W granicach zakreślonych linią XXXX przewóz towarów drogą wodną do portu docelowego jest tańszy niż transport kolejowy lub mieszany kolejowo-morski. (S. T u r c zy n ow i cz, T. Tilling e r: Konieczność budowy drogi wodnej przez Polesie i osuszania go celem połączenia zachodnich centrów przemysłowych ze źródłami surowców środkowej i wschodniej Europy, Warszawa 1925). 
do robót hydrotechnicznych mogły być dopuszczone również przedsiębiorstwa prywatne, ale wyłącznie na podstawie koncesji udzielanej przez MRP i to na okres nie dłuższy niż 90 lat $^{55}$.

Ale i te działania nie przyniosły efektu. Przez cały okres dwudziestolecia międzywojennego ambitne plany budowy sieci dróg wodnych, a szczególnie tych dwóch najważniejszych, tworzących „wielki krzyż”, czyli kanału Śląsk-Bałtyk oraz połączenia bałtycko-czarnomorskiego przez Polesie, wciąż pozostawały jedynie planami. W promowaniu tych koncepcji Tillinger był niestrudzony. Na łamach prasy inżynierskiej publikował obszerne opracowania dowodząc zarówno technicznej wykonalności, jak i ekonomicznej oraz społecznej opłacalności tych inwestycji. Zachwalając ideę Kanału Węglowego, podkreślał, że został on zaprojektowany „według nowoczesnej zasady prowadzenia drogi wodnej w kierunku rzeczywistych potrzeby przewozowej, a nie przypadkowego biegu większych lub mniejszych rzek”, czym dość wyraźnie wpisywał się w nurt każący traktować technikę jako narzędzie podboju natury ${ }^{56}$.

Koncepcja budowy Kanału Węglowego wiązała się w ścisły sposób z ideą transeuropejskiej drogi wodnej Zachód-Wschód. Według projektu Tillingera odnogi tego kanału, odchodząc od niego w okolicach Łęczycy na wschód, w kierunku Warszawy i na zachód do Poznania, tworzyły wyraźną oś Zachód-Wschód, poprzeczne ramię „wielkiego krzyża kanałów". Zdaniem inżyniera to poprzeczne ramię stanowiło znacznie dogodniejsze przedłużenie transeuropejskiej drogi wodnej niż rozważana głównie przez hydrotechników niemieckich trasa biegnąca przez Kanał Bydgoski i środkową Wisłę ${ }^{57}$.

\section{Drogi wodne a melioracja Polesia}

Wspomniana we wstępie zależność pomiędzy budową dróg wodnych na Polesiu a jego planowanym osuszeniem nie była ani tak prosta, ani tak jednoznacznie korzystna, jak niekiedy uważano. 0 ile przy inwestycjach tego typu większe kanały osuszające rzeczywiście wykorzystuje się z powodzeniem do spławu towarów, to wpływ, jaki na lokalne stosunki wodne może mieć budowa kanałów żeglugowych lub regulowanie rzek z myślą o przystosowaniu ich do ruchu jednostek o dużym tonażu, jest bardziej złożony. Nie ma wiele przesady w twierdzeniu, że na Polesiu interesy żeglugi i rolnictwa były w dużej mierze sprzeczne. I nie chodziło tu tylko o nieprawidłowo wykonane i źle utrzymywane cieki sztuczne, jak Kanał Ogińskiego czy stary Kanał Królewski. 0 tym ostatnim w 1924 r. Tillinger pisał, że „obecnie ist-

${ }^{55}$ Ustawa z dnia 31 lipca 1924 r. zmieniająca niektóre postanowienia ustawy z dnia 9 lipca 1919 r. o budowie kanałów żeglownych, tudzież regulacji rzek żeglownych i spławnych, Dz. U. nr 79, poz. 768.

${ }^{56}$ T. Till in ge r: Droga wodna transeuropejska (cz. I), „Przegląd Techniczny” t. 62:1924 nr 18 s. 201.

57 Tamże. 
niejący kanał nie tylko nie osusza przylegających miejscowości, ale je w niektórych miejscach nawet zabagnia"58. Takie sytuacje mogły być naprawione, co też w 1924 r. zaproponował Tillinger - w swoim planie modernizacji drogi wodnej Brześć-Pińsk założył obniżenie poziomu wody w Kanale Królewskim o 1,5 do 2 m, dzięki czemu można byłoby osuszyć „tysiące kilometrów kwadratowych okolicznych bagien”59.

Trudności w pogodzeniu sprzecznych interesów rolnictwa i żeglugi na Polesiu wynikały wprost z założeń teorii robót hydrotechnicznych. Regulacja rzek, polegająca m.in. na zmniejszaniu prędkości przepływu za pomocą piętrzenia jazami, szczególnie w przypadku cieków płynących - jak Prypeć - w niemal płaskim terenie z reguły okupiona jest koniecznością zalania stosunkowo dużych obszarów przybrzeżnych. Można oczywiście w takiej sytuacji stosować obwałowanie rzeki, ale i tak odwodnienie położonych za wałami terenów staje się niemożliwe, o ile nie sięgnie się do metody przepompowywania wody z tak powstałych polderów. Rozwiązanie takie, tradycyjnie stosowane w Holandii, rozważano również w przypadku Polesia, zarówno po polskiej, jak i po sowieckiej stronie. W Związku Radzieckim w ramach planowanej w połowie lat 30. budowy jazów spiętrzających na dolnej Prypeci oraz dolnym i średnim biegu Dniepru studia nad opłacalnością obwałowania rzek i pompowania wody z polderów prowadził wybitny hydrolog rosyjski, ceniony również w Polsce, Jewgienij Oppokow ${ }^{60}$.

O tym, że poprowadzenie Prypecią dużej drogi wodnej spowodowałoby jeszcze większe zabagnienie Polesia, już w 1921 r. przekonywał Ingarden. 0 ile w przypadku przystosowania rzeki do żeglugi mniejszych jednostek wystarczyłoby lekkie sprostowanie jej biegu, to dla ruchu barek 600 lub 1000 -tonowych konieczna była budowa jazów, czego nieuniknionym skutkiem byłoby trwałe zalanie dużej części doliny Prypeci. Ingarden uważał, że „pod względem gospodarczym musiałoby [to] spowodować większe szkody, niż mogą być uzyskane korzyści z używania do żeglugi statków o większym udźwigu"61. Podkreślał, że z uwagi na dużą chłonność podłoża torfia-

${ }^{58}$ T. T i ll i n ge r: Droga wodna transeuropejska (cz. II), „Przegląd Techniczny” t. 62:1924 nr 19 s. 212

${ }^{59}$ Tamże. Co więcej, w „odpowiednio ujętej operacji melioracyjnej” Tillinger upatrywał możliwość odzyskania części wydatków poniesionych na modernizację kanału. Miał na myśli wykup zabagnionych terenów, a następnie ich rozparcelowanie po osuszeniu. Inną formą mogła być opłata adiacencka gwarantująca podział zysku wynikającego ze wzrostu wartości terenów pomiędzy właścicielem terenu a podmiotem - czy to publicznym czy prywatnym, który zainwestował w prace melioracyjne. Ostatecznie jednak, w projekcie założono obniżenie dna kanału o 0,7 metra na wododziale, przy czym - jak zaznaczał Tillinger - „w przyszłości w miarę potrzeb rolnictwa, poziom ten będzie mógł być obniżony jeszcze o dalsze 0,8 - $1 \mathrm{~m}$ ". Zob. T. Tillin ger: Przyszłe drogi wodne na Ziemiach Zachodnich, „Prace Instytutu Badania Stanu Gospodarczego Ziem Wschodnich" t. 1:1927 nr 1 s. 37.

${ }^{60} \mathrm{~J}$. S z o wh e n o w : Rentowność sztucznego odwadniania nizin obwałowanych, „Gospodarka Wodna" t. 3: 1937 nr 5 s. 290-291.

${ }^{61} \mathrm{R}$. In ga r d en : Rzeki i kanały żeglowne $w$ b. trzech zaborach i znaczenie ich gospodarcze dla Polski, Warszawa 1921, s. 468. 
stego pomysł piętrzenia wody na tych terenach stawał się problematyczny. Inżynier spodziewał się również trudności z zapewnieniem odpowiedniej ilości wody traconej w wyniku śluzowania. Co więcej, przestrzegał, że w efekcie akcji melioracyjnej na Polesiu ilość wody w rzekach zmniejszy się tak bardzo, że utrzymanie na nich parametrów żeglugowych w standardzie 400 ton będzie mogło okazać się niemożliwe ${ }^{62}$.

Wszystkie te rozważania opierały się na założeniu, że nie uda się obniżyć poziomu Prypeci w punkcie, w którym rzeka opuszcza terytorium Polski. Na całym odcinku od źródeł aż do granicy sowieckiej Prypeć miała niewielki spadek, przy czym większość tego spadku przypadała oczywiście na górny bieg rzeki. Od Pińska do granicy państwa rzeka płynęła niemal w płaskim terenie. Ewentualne obniżenie poziomu w tym najdalej na wschód wysuniętym punkcie wymagało porozumienia się z Sowietami, a to $\mathrm{w}$ realiach politycznych dwudziestolecia międzywojennego nie było proste. Nie bez powodu ta właśnie kwestia stanowiła jedną z ważniejszych osi dyskusji toczącej się wokół planów melioracji Polesia. W sporze tym uczestniczyli nie tylko inżynierowie - co oczywiste - lecz również politycy i wojskowi. 0 ile ci pierwsi z reguły byli zdania, że odwodnienie Polesia było wykonalne w każdych warunkach, to ci drudzy reprezentowali stanowisko raczej sceptyczne.

Trudno jest jednoznacznie wskazać autorów tego poglądu. Niewątpliwie wiele dla jego upowszechnienia zrobili trzej eksperci Ligi Narodów w raporcie podsumowującym swój pobyt w Polsce w 1926 r.63 Ich zdaniem podstawową przeszkodą na drodze do skutecznego odwodnienia Polesia była „absolutnie niewystarczająca pojemność Prypeci”. Ich zdaniem „ażeby podnieść zdolność przepływu Prypeci, można powiększyć jej spadek na całej długości, obniżając poziom Dniepru na terytorjum rosyjskiem w miejscu ujścia Prypeci”64. Drugą możliwością było zmniejszenie nadmiaru płynących Prypecią wód poprzez przerzucenie ich części do Bugu, co miałoby tę dodatkową zaletę, że poprawiłoby warunki żeglugowe na tej dość ubogiej w wodę rzece.

Przeciwny tezie, że uregulowanie sowieckiego odcinka Prypeci było warunkiem koniecznym, by móc skutecznie odwodnić Polesie, był natomiast Ingarden, w czym, jak rzadko, zgadzał się z nim Tillinger. Ten ostatni, wypowiadając się podczas specjalnej konferencji w sprawie osuszenia i zagospodarowania Polesia zorganizowanej w połowie października 1928 r. przez Biuro Projektu Melioracji Polesia, wprost wykpiwał to stanowisko kąśliwie stwierdzając:

62 Tamże s. 606.

${ }^{63}$ Przebieg i rezultaty tej wizyty zostały omówione w dalszej części artykułu.

${ }^{64}$ Liga Narodów. Komisja Doradcza i Techniczna Komunikacji i Tranzytu: Sprawozdanie komitetu ekspertów przedłożone rzq̨dowi polskiemu przez Ligę Narodów o programie budowy dróg wodnych w Polsce, wykorzystaniu ujść morskich i dróg dojazdowych do nich dla przewozu węgla, oraz o osuszeniu bagien poleskich, Warszawa 1928, s. 46. 
A więc gdyby zamiast Rosji było morze i Prypeć wpadałaby w tem miejscu do niego,

to Polesie według tego rozumowania nie mogłoby być osuszone z powodu zbyt słabego spadku doliny rzeki ${ }^{65}$

Poza tym Tillinger przypuszczał, że do regulacji dolnego biegu Prypeci jednak dojdzie, bowiem znaczenie drogi wodnej Prypeć-Bug doceniali również Sowieci ${ }^{66}$.

Mimo tego wyjątkowo zgodnego - jak na dość chłodne relacje pomiędzy obydwoma czołowymi polskimi hydrotechnikami - frontu, pogląd o uzależnieniu sukcesu polskich prac melioracyjnych od Sowietów był dość powszechny. Nie brakowało również opinii idących jeszcze dalej, a mianowicie mówiących, że sowieckie inwestycje hydrotechniczne na Ukrainie, a przede wszystkim budowa zbiornika retencyjnego Dnieprostroju czyli Dnieprowskiej Elektrowni Wodnej wpłyną poprzez spiętrzenie wód tej rzeki negatywnie na stosunki wodne w całej zlewni Dniepru, a zatem również w dorzeczu Prypeci. Pogląd taki wyznawał m.in. porucznik Jerzy Niezbrzycki (1902-1968) zajmujący się w Oddziale II Sztabu Generalnego Wojska Polskiego problematyką wschodnią. W wydanym w 1930 r. „opisie wojskowo-geograficznym" Polesia stwierdzał, że budowa Dnieprostroju oraz ewentualnie innych zapór na Dnieprze „odbije się prędzej czy później na stanie zabagnienia Polesia”, spowoduje bowiem „zmniejszenie chyżości prądu, a co za tem idzie i odpływu z górnego biegu Dniepru i jego dopływów"67.

Niezbrzycki był niewątpliwie świetnym specjalistą w zakresie wywiadu wojskowego, jednym z liderów „kierunku wschodniego i niezaprzeczalnie jego szarą eminencją"68, ale na hydrologii mógł się jednak nie znać. Józef Pruchnik, piastujący wówczas funkcję dyrektora Biura Projektu Melioracji Polesia, wytknął mu upowszechnianie tego błędnego poglądu i to w dodatku w książce ukazującej się pod szyldem renomowanego przecież Wojskowego Instytutu Naukowo-Wydawniczego. Nie trudno dostrzec powody jego oburzenia - przyjęcie takiego poglądu za prawdziwy postawiłoby pod znakiem zapytania sens funkcjonowania kierowanej przez niego instytucji. Zdaniem Pruchnika największym grzechem porucznika było to, że formułował on swoje tezy w sposób tak „bardzo kategoryczny”69.

${ }^{65}$ T. Tilli ng e r: Regulacja Prypeci, „Inżynieria Rolna” t. 3: 1928 nr 5 s. 248.

${ }^{66} \mathrm{~T}$. Tilling e r: Przyszłe drogi wodne... s. 37.

${ }^{67}$ J. N i e z b r z y c ki : Polesie: opis wojskowo-geograficzny i studjum terenu, Warszawa 1930, s. 217.

${ }^{68}$ L. G o n d e k: Wywiad polski w Trzeciej Rzeszy 1933-1939 : zarys struktury, taktyki i efektów obronnego działania, Warszawa 1982, s. 161.

${ }^{69}$ J. Pru ch nik: Postępy prac przy meljoracji Polesia. Sprawozdanie za rok 1930, „Czasopismo Techniczne" t. 49: $1931 \mathrm{nr} 21$ s. 351. 


\section{Eksperckim okiem}

W połowie lat 20. w ten zajmujący jak dotąd wyłącznie krajowe kręgi dyskurs wmieszali się specjaliści zachodni, i to - należy dodać - na własne życzenie Polaków. Wspomniana już komisja ekspertów Ligi Narodów, wizytująca Polskę w 1926 r., niemal dosłownie zatrzęsła dotychczasową polityką w kwestii żeglugi śródlądowej. Z jednej strony ich rekomendacje podważały sensowność projektów, których swego rodzaju eksperckiego podżyrowania spodziewał się rząd zapraszając komisję do Polski, a z drugiej - sugerowali kierunki działań albo wcześniej zarzuconych albo nie mających zgoła nic wspólnego z pierwotnym celem ich przyjazdu.

Za praprzyczynę zdarzeń, które doprowadziły do tej wizyty, należy uznać pomysł polskiego delegata w działającej przy Lidze Narodów Komisji do spraw Komunikacji i Tranzytu (Committee for Communications and Transit), prof. Bohdana Winiarskiego. Komisja powstała w $1921 \mathrm{r}$. jako odpowiedź na pilną potrzebę uregulowania kwestii żeglugi śródlądowej w powojennej Europie. Jednym z pierwszych kroków podjętych w tym celu było rozesłanie do państw członkowskich ankiety, której wyniki miały dać wyobrażenie o aktualnym stanie żeglugi na drogach wodnych kontynentu i jej najpilniejszych potrzebach. Do przeprowadzenia tych studiów powołano - właśnie na wniosek Winiarskiego - specjalną komisję ekspertów. Nieco później, działając na polecenie polskiego MSZ, zaprosił on trzech członków tej komisji do Polski z prośbą o zaopiniowanie projektu kanału węglowego.

W skład komisji ekspertów weszli: mjr James Francis Case (1868-1929), Amerykanin, były dyrektor robót publicznych na Filipinach i doradca firmy Ulen, dr Guillaume Paul Nijhoff (1895-1932), były inżynier holenderskiej służby dróg i mostów (Rijkswaterstaat), pracujący wówczas jako doradca w Brukseli, oraz Pierre Henri Watier (1882-1937), szef Dyrekcji Dróg Wodnych i Portów Morskich (Direction des ports maritimes et des voies navigables) we francuskim ministerstwie robót publicznych. Oprócz nich miał przyjechać sekretarz sekcji tranzytowej Ligii Narodów, Johan Romein, holenderski inżynier, który na jesieni 1924 r. już raz był w Polsce, gdy $\mathrm{z}$ ramienia Ligii zapoznawał się z polskimi racjami przeciw umiędzynarodowieniu Warty i Noteci ${ }^{70}$.

Nie jest pewne, czy o inicjatywie MSZ od początku był poinformowany resort robót publicznych. Dopiero bowiem, gdy podróż ekspertów, planowana wstępnie na drugą połowę maja 1926 r., z powodu zamachu stanu w Warszawie, została przełożona o miesiąc, ministerstwo „zawiadomione” o ich przyjeździe przedstawiło znacznie dłuższą listę zagadnień do oceny. Oprócz kanału węglowego mieli zbadać także m.in. możliwość budowy drogi wodnej Wisła-Prypećn ${ }^{71}$. Charakterystyczny jest

${ }^{70}$ Więcej o powodach polskiego sprzeciwu zob. A. Ko n o p ka: Sprawa umiędzynarodowienia polskich odcinków Warty i Noteci, „Czasopismo Techniczne” t. 50: 1932 nr 10 s. 154-159.

${ }^{71}$ Liga Narodów: Sprawozdanie komitetu..., s. 5. 
sposób, w jaki tamte wydarzenia wspominał inż. Alfred Konopka, naczelnik wydziału w Ministerstwie Robót Publicznych, nazywając tę będącą „w ścisłym związku z melioracją Polesia” inwestycję mianem „daleko ważniejszej” od kanału węglowego ${ }^{72}$.

Tak się złożyło, że na tydzień przed przyjazdem ekspertów Konopka widział się w Antwerpii z jednym z nich, Henrym Watierem. Do spotkania doszło podczas zjazdu Zarządu Międzynarodowego Związku Kongresów Żeglugi. Jak wspomina Konopka, to sam Watier poinformował go o wątpliwościach swoich oraz dwóch pozostałych członków komisji eksperckiej co do projektowanego przez Polskę kanału węglowego. Wątpliwości te dotyczyły nie tylko trudności technicznych związanych z zasilaniem wodą stanowiska szczytowego przypadającego na dziale wód pomiędzy Wartą a Przemszą, lecz przede wszystkim Watier, Case i Nijhoff powątpiewali w opłacalność całej inwestycji. Uważali otóż - w czym, jak się zdaje, zgadzał się z nimi Konopka - że budowa kanału łączącego Górny Śląsk z portami nad Bałtykiem nie miała sensu, zwiększone bowiem zapotrzebowanie na polski węgiel na rynkach zagranicznych było zjawiskiem przejściowym, wywołanym przez masowe strajki górników angielskich. Zanim kanał zostałby ukończony - argumentował Watier „ustanie zapewne strajk węglowy w Anglii i jego skutki, ustanie więc i ten chwilowo wielki" eksport węgla z Polski ${ }^{73}$.

Gdyby jednak wywóz utrzymał się na podwyższonym poziomie, to według Francuza nie byłby to eksport na tyle wysoki, by przewóz węgla do Gdańska nie mógł odbywać się koleją, tak jak zresztą miało to miejsce od zakończenia wojny. Nie przekonywał go argument, że kanał byłby przecież wykorzystywany do przewozu tego surowca do odbiorców krajowych, na stosunkowo bowiem krótkich trasach transport wodny nie był aż tak konkurencyjny wobec kolejowego. Gdyby przewozy na trasach krajowych, przede wszystkim zaopatrujące „ogromną wschodnią połać państwa [która] będzie zawsze konsumentem węgla”, miałyby przechodzić drogą wodną, to Watier widział więcej sensu w wykorzystaniu Wisły, której uregulowanie byłoby znacznie tańsze niż „budowa nowego kanału w dość ciężkich warunkach”. W takim układzie dużego znaczenia nabierała kwestia wschodniej odnogi takiej wiślanej magistrali węglowej i - jak podsumowywał Konopka - „z tego też powodu p. Watier zainteresował się szczególnie Polesiem i drogą wodną Wschód-Zachód i postanowił sprawę tę omówić ze swymi kolegami"74.

Najwyraźniej zatem już w chwili przyjazdu do Polski, eksperci Ligi Narodów mieli wyrobioną opinię na temat spraw, które mieli badać. Zbieżność z poglądami Konopki mogła być zupełnie przypadkowa, niemniej miał on sposobność, by zawczasu zasugerować im określony punkt widzenia. Czy tak było - tego w świetle dostępnych dokumentów ani dowieść ani zaprzeczyć się nie da. Konopka bez

\footnotetext{
${ }^{72}$ A. Kon opka: Eksperci Ligi Narodów o polskich drogach wodnych, „Czasopismo Techniczne" t. 44: 1926 nr 21 s. 361.

${ }^{73}$ Tamże.

${ }^{74}$ Tamże s. 362.
} 
wątpienia był świetnym specjalistą w dziedzinie żeglugi śródlądowej. Przed wojną wykładał w Cesarsko-Królewskiej Szkole Politechnicznej we Lwowie, a później pracował w austrowęgierskim ministerstwie robót publicznych, cały czas obszernie publikując na tematy związane z technicznymi i prawnymi aspektami budowy i funkcjonowania dróg wodnych.

Ostatecznie Nijhoff i Case najwyraźniej podzielili pogląd Francuza, cała trójka bowiem właśnie od Polesia rozpoczęła swój blisko miesięczny objazd po Polsce. Po odbyciu kilku spotkań w stolicy eksperci oraz towarzyszący im inżynierowie z Ministerstwa Robót Publicznych 2 lipca dokonali inspekcji Kanału Królewskiego i Piny aż do Pińska, a nazajutrz, po objeździe Prypeci - powrócili do Warszawy. Dopiero wtedy udali się w inne rejony kraju zwiedzając bieg rzek oraz tereny na trasie projektowanych kanałów. Odwiedzili również m.in. Gdańsk, Toruń, Tczew i Gdynię. Podsumowując rezultaty wizyty komisji, Konopka powtórzył jej radę, „że nie należy rozdrabniać wysiłków - jak to u nas niestety w zwyczaju - a za to całą uwagę i szczególną opiekę zwrócić przede wszystkim na Wisłę i drogę wodną Wschód-Zachód"75.

Zanim 24 lipca opuścili Polskę, Case i Nijhoff odwiedzili w Warszawie Ministra Rolnictwa i Dóbr Państwowych, Aleksandra Raczyńskiego (1872-1941), którego zapewnili, że widzą duże szanse uzyskania za granicą funduszy na przeprowadzenie osuszenia Polesia i zapowiedzieli ponowny przyjazd do Polski w celu przeprowadzenia dokładniejszych studiów terenowych ${ }^{76}$. Zadanie to przypadło Holendrowi, który wrócił do Polski po kilku tygodniach, żeby zebrać dodatkowe informacje niezbędne do przygotowania raportu z prac komisji, „a przytem zwiedzić jeszcze niektóre już rozpoczęte charakterystyczne roboty na Polesiu"77. W podróży towarzyszył mu tym razem poseł holenderski w Polsce, H.J. van Son oraz pierwszy sekretarz poselstwa amerykańskiego, Stanley Hawks. Ponadto ze strony gospodarzy w objeździe wziął udział wiceminister robót publicznych Kazimierz Górski oraz dyrektor departamentu wodnego inż. Marian Prokopowicz. Grupa zapoznała się wówczas m.in. pracami melioracyjnymi prowadzonymi w dorzeczu rzeki Hrywdy oraz odwiedziła stację doświadczalną w Sarnach. Uczestnicy wyprawy dokonali również inspekcji Prypeci na odcinku od Pińska do Wolańskich Mostów - przeprawy kolejowej nad Prypecią na linii kolejowej Łuniniec-Sarny.

Efektem obu tych wypraw był specjalny raport, który został załączony do oficjalnego sprawozdania wieńczącego pracę komisji eksperckiej. Raport zawierał dość dokładną analizę możliwości osuszenia Polesia, przy czym eksperci szeroko odwoływali się do doświadczeń wyniesionych ze swoich krajów. Co nie powinno dziwić,

${ }^{75}$ Tamże s. 363.

${ }^{76}$ Kapitały zagraniczne na osuszenie Polesia, „Robotnik” t. 32: 1926 nr 207.

${ }^{77}$ A. Ko n o p ka: Eksperci Ligi Narodów... s. 362. Nie wiadomo dokładnie, czy objazd miał miejsce w pierwszych dniach września, jak wspomina Konopka, czy w końcu miesiąca jak podają inne relacje (zob. m.in. Na Polesie przybyli, „Kurier Warszawski” t. 106: 1926 nr 267; „Życie Polesia” t. 3:1926 nr 35; „Przyjaciel Ludu” t. 38:1926 nr 40) 
szczególnie często padał przykład Holandii, przede wszystkim prowadzonej tam akcji osuszenia Zuiderzee ${ }^{78}$. Oprócz określenia zakresu niezbędnych prac regulacyjnych i melioracyjnych, raport sugerował też konkretne rozwiązania techniczne ${ }^{79}$.

Eksperci podpowiadali ponadto, jak do zadania osuszenia Polesia podejść od strony organizacyjnej i prawnej. Załączyli wreszcie szacunkowe obliczenia kosztu całej operacji, począwszy od regulacji rzek aż po melioracje szczegółowe na gruntach ornych i łąkach - było to okrągłe 450 milionów złotych, radząc przy tym, jak pozyskać zainteresowanie kapitału zagranicznego tą inwestycją. Konkluzje raportu podchwyciła krajowa prasa, nieco na wyrost informując o rzekomo już pewnym udziale inwestorów zachodnich w tym przedsięwzięciu ${ }^{80}$. Jeśli sugerować się tonem relacji prasowych komentujących wizytę ekspertów Ligi Narodów, to właśnie ich poglądami na szanse zmeliorowania Polesia opinia publiczna w Polsce emocjonowała się najbardziej.

Stanowisko ekspertów zachodnich wobec kwestii osuszenia Polesia, wyrażane przez nich zarówno podczas spotkań z polskimi oficjelami, jak i sformułowane później w postaci raportu, stało się na kilka kolejnych lat najsilniejszym argumentem w rękach zwolenników tego przedsięwzięcia. Wytworzyło przekonanie, że jest to zadanie nie tylko wykonalne, lecz leżące niemal w zasięgu ręki, a kapitał międzynarodowy tylko czeka, by w poleskich błotach - jeśli użyć kolokwialnego, ale jakże trafnego w tym kontekście określenia - utopić miliony dolarów ${ }^{81}$.

Natomiast w kwestii, która zasadniczo przywiodła ich do Polski, to jest w sprawie dróg wodnych, eksperci odradzali budowę kanału węglowego zapewniając: „że dla przewozu węgla śląskiego wodą należy przedewszystkiem przeprowadzić całkowitą regulację Wisły, wraz z budową kanału bocznego (lateralnego) od zagłębia węglowego aż do okolic Krakowa"82.

Co do kolejności robót, sugerowali, aby po przeprowadzeniu gruntownych badań hydrologicznych i geologicznych na głównych kierunkach projektowanych inwestycji, przystąpić do wykonania krótkiego łącznika pomiędzy jeziorem Gopło a Wartą. Kanał taki, łącząc systematy Wisły i Warty, w dogodny sposób spiąłby polskie drogi wodne z siecią zachodnioeuropejską. Dodatkowo, w miejscu łączenia się kanału z Wartą eksperci postulowali budowę portu przeładunkowego dla węgla dowożonego ze Śląska koleją. Taki kombinowany system przewozu był ich zdaniem znacznie korzystniejszy niż proponowany kanał węglowy.

\footnotetext{
${ }^{78}$ Liga Narodów: Sprawozdanie komitetu..., s. 49-51.

${ }^{79}$ Tamże s. 45.

${ }^{80}$ Delegaci Ligi Narodów już zwiedzili Polesie, „Goniec Nadwiślański” t. 2: 1926 nr 168; Kapitały na osuszenie Polesia Polska znajdzie z łatwościq̨. Opinija rzeczoznawców Ligi narodów, „Głos Polski” t.9: 1926 nr 208; Kapitał zagraniczny zajął się sprawą osuszenia Polesia, „Ilustrowany Kurier Codzienny" t. 17: 1926 nr 208; Kopalnie złota w błotach poleskich zainteresowały kapitalistów holenderskich, „Głos Polski” t. 11:1926 nr 259.

${ }^{81}$ Liga Narodów: Sprawozdanie komitetu..., s. 53.

${ }^{82}$ Tamże s. 6.
} 
W dalszej kolejności eksperci Ligi Narodów proponowali przeprowadzić równolegle regulację Wisły jako zasadniczej dla kraju osi południe-północ oraz budowę drogi wodnej Bug-Prypeć, która stanowiłaby przedłużenie „polskiej osi hydraulicznej zachód-wschód", rozpoczynającej się od Noteci i biegnącej na wschód przez Brdę, środkową Wisłę i Narew aż do Bugu ${ }^{83}$. Autorzy raportu wprost mówili o tej drodze jako o przedłużeniu Mittellandkanal, tonując jednak entuzjazm (uspokajając obawy?) stwierdzeniem, że taka transeuropejska droga nie byłaby wykorzystywana do przewozu towarów z jednego krańca na drugi, z wyjątkiem może blokady morskiej. Eksperci raczej spodziewali się na niej całej serii przewozów o mniejszym lub większym zasięgu ${ }^{84}$.

W raporcie zwraca uwagę konsekwentne podkreślanie interesu ekonomicznego i politycznego Polski, a także rzeczowa argumentacja proponowanych rozwiązań technicznych. Mimo to, mniej lub bardziej świadomie, autorzy raportu wpisali się w spór toczący się w krajowym środowisku inżynierskim praktycznie od końca I wojny światowej. Zasadniczo żadna ze stron tego sporu o przyszły kształt polskich dróg wodnych nie mogła w pełni utożsamiać się z całością prezentowanych w raporcie poglądów, choć Tillinger i skupieni wokół niego zwolennicy budowy transeuropejskiej drogi wodnej oraz odwodnienia Polesia musieli czuć się usatysfakcjonowani. Nie sposób zresztą nie zauważyć, że nawet przybliżony koszt inwestycji, szacowany przez specjalistów zagranicznych zbytnio nie odbiegał od kwoty obliczonej i podanej do publicznej wiadomości przez Tillingera i Turczynowicza rok wcześniejej.

W szczegółach rekomendacje komisji, kwestionując celowość flagowego pomysłu lansowanego przez Tillingera, czyli kanału węglowego, do pewnego stopnia mogły podważać jego pozycję jako niekwestionowanego (dotąd) znawcy tematu. Z drugiej strony podnosząc kwestię budowy drogi transeuropejskiej, eksperci Ligi Narodów wzmocnili siłę jego argumentów w dyskusji nad tym, odłożonym z powodów politycznych projektem, czym jednocześnie zantagonizowali przeciwników koncepcji przedłużania transeuropejskiej drogi wodnej z Ingardenem na czele. W ostatecznym jednak rozrachunku to krajowe środowisko inżynierskie i władze państwowe same musiały odpowiedzieć na pytanie o kształt i priorytety odrodzonej Rzeczpospolitej.

\section{Zakończenie}

Poglądy na to, jakie zadania krajowa sieć dróg wodnych miała spełniać, jaki powinna mieć kształt, do ruchu jakich jednostek miała być przystosowana i jak należało sfinansować tego rodzaju inwestycję, zmieniały się w okresie II Rzeczpospolitej dość

\footnotetext{
${ }^{83}$ Tamże s. 17.

${ }^{84}$ Tamże s. 33

${ }^{85} \mathrm{~S}$. T u r c zy n o w i cz, T. Till ing e r : Konieczność budowy... s. 42.
} 
dynamicznie. Wśród czynników determinujących te zmiany należałoby wskazać nie tylko ówczesne, dopiero kształtujące się ustawodawstwo wodne, ogólną sytuację gospodarczą oraz kondycję finansową państwa, ale także sytuację międzynarodową, a nawet animozje $w$ krajowym środowisku inżynierskim, wynikające czy to z różnic $\mathrm{w}$ doświadczeniu zawodowym i reprezentowanej szkole inżynierskiej, czy to z powodów osobistych ambicji. Podobny spór toczył się wokół kwestii osuszenia Polesia. To, że aż do wybuchu II wojny światowej nie stworzono wspólnej wizji uwzględniającej stanowiska obu tak ściśle związanych ze sobą zagadnień nie powinno dziwić, skoro nie wypracowano spójnego planu dla żadnej z nich z osobna.

W praktyce inżynierskiej nie ma niczego złego w sporze co do wyboru najlepszych rozwiązań danego problemu technicznego. Wymiana przeciwstawnych nawet poglądów jest tu jak najbardziej naturalna, a nawet pożądana - dyskusja taka nie tylko redukuje ryzyko popełnienia błędów lub pominięcia w procesie projektowym takich czy innych uwarunkowań, lecz także daje szansę na wykorzystanie zróżnicowanego doświadczenia zawodowego zaangażowanych $w$ ten dyskurs inżynierów. Z tego punktu widzenia w okresie międzywojennym sytuacja - a tym samym i stworzone przez nią szanse - była zupełnie wyjątkowa: pracę nad wielkimi zadaniami modernizacyjnymi odrodzonej Rzeczpospolitej podejmowali inżynierowie wykształceni w najlepszych szkołach technicznych Europy i posiadający wieloletnie doświadczenie pracy w służbie hydrotechnicznej Niemiec, Rosji i Austro-Węgier.

Czy szansę tę w pełni wówczas wykorzystano? W tym przypadku na pewno nie. Trwająca przez cały okres 20-lecia międzywojennego dyskusja zarówno nad kwestią melioracji Polesia jak i nad rozbudową krajowej sieci dróg wodnych, poza kilkoma dość drobnymi przedsięwzięciami, nie przyniosła żadnych konkretnych rezultatów. O ile utrata Ziem Wschodnich, która nastąpiła w wyniku umów jałtańskich - by użyć eufemizmu - rozwiązała dla Polaków kwestię melioracji Polesia raz na zawsze, to końca trwającej już od przeszło 70 lat czczej, jak dotąd, debaty nad przyszłością krajowych dróg wodnych nadal nie widać.

Praca powstała w wyniku realizacji projektu badawczego nr 2015/19/B/ HS3/03553 finansowanego ze środków Narodowego Centrum Nauki.

\section{BIBLIOGRAFIA}

\section{Prasa}

„Czasopismo Techniczne” 1926, 1931, 1932

„Głos Polski” 1926

„Goniec Nadwiślański” 1926

„Gospodarka Wodna” 1936, 1937 


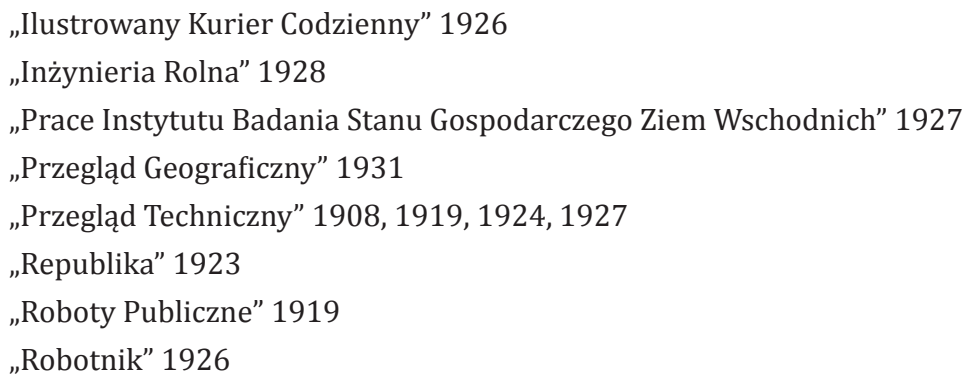

\section{Dokumenty drukowane}

Dziennik urzędowy Ministerstwa spraw wewnętrznych, 1925, poz.161, s. 33.

Dziennik urzędowy Ministerstwa spraw wewnętrznych, 1923, poz. 158, s. 20.

Liga Narodów. Komisja Doradcza i Techniczna Komunikacji i Tranzytu: Sprawozdanie komitetu ekspertów przedłożone rzq̨dowi polskiemu przez Ligę Narodów o programie budowy dróg wodnych w Polsce, wykorzystaniu ujść morskich i dróg dojazdowych do nich dla przewozu węgla, oraz o osuszeniu bagien poleskich, Warszawa 1928.

Ministerstwo Robót Publicznych do Marszałka Sejmu Ustawodawczego RP, Druk nr 404, Zał. 2, 19 kwietnia $1919 \mathrm{r}$.

Sejm Ustawodawczy Rzeczypospolitej Polskiej: Sprawozdanie połączonych komisji robót publicznych i wodnej o przedłożeniu Rządu w przedmiocie budowy dróg wodnych, 1919, Druk nr 639.

Sprawozdanie stenograficzne z 21 posiedzenia Sejmu Ustawodawczego z dnia 29 marca $1919 r$.

Sprawozdanie stenograficzne z 66 posiedzenia Sejmu Ustawodawczego z dnia 9 lipca 1919 r.

Ustawa z dnia 9 lipca 1919 roku o budowie kanałów żeglownych, tudzież regulacji rzek żeglownych i spławnych, Dz.Pr.P.P. 1919 nr 59 poz. 356.

Ustawa z dnia 31 lipca 1924 r. zmieniająca niektóre postanowienia ustawy z dnia 9 lipca 1919 r. o budowie kanałów żeglownych, tudzież regulacji rzek żeglownych i spławnych, Dz. U. nr 79, poz. 768.

\section{Opracowania}

J. Bu nd: Rozwój kolejnictwa małopolskiego w okresie 80-lecia (1850-1930), działalności Krakowskiej Izby Przemysłowo-Handlowej oraz przebieg starań o wykonanie Ustawy Koerberowskiej o budowie dróg wodnych, Kraków 1930.

P. E hl e r s: Binnenwasserstraßen des Ostens : mit einem Längenschnitt und einer farbigen Karte, Danzig 1917.

P. Ehl er s: Die Wasserstraße Danzig-Ukraine, Danzig 1918.

J. G o cl on: Ustrój Rady Ministrów, ministerstw i system kontroli resortowej w Polsce w latach 1918-1928, „Folia Iuridica Universitatis Wratislaviensis” t. 2:2013 nr 1.

L. G o n d e k: Wywiad polski w Trzeciej Rzeszy 1933-1939 : zarys struktury, taktyki i efektów obronnego działania, Warszawa 1982.

K. Gr ü n b e rg, B. S pren gel: Trudne sqsiedztwo : stosunki polsko-ukraińskie $w$ X-XX wie$k u$, Warszawa 2005. 
R. In garden : Skutek gospodarczy projektowanych w Królestwie Kongresowem kanałów żeglownych, Kraków 1920.

R. In g a r d e n : Rzeki i kanały żeglowne $w$ b. trzech zaborach i znaczenie ich gospodarcze dla Polski, Warszawa 1921.

J. Li p k o w s ki , T. T ill ing e r : Memorjał finansowy, techniczny i ekonomiczny dołaczony do podania o zatwierdzenie Statutów Spółki Akcyjnej „Kanał Węglowy Śląsk-Gdańsk” z odnogami do Warszawy i do Poznania, Warszawa 1921.

J. N i e z b r zy c ki : Polesie: opis wojskowo-geograficzny i studjum terenu, Warszawa 1930.

T. T ill in g e r : Baltiysko-Chernomorskiy morskoy kanal, Sankt-Peterburg 1908.

S. T u r c z y n o w i cz, T. Till in g e r: Konieczność budowy drogi wodnej przez Polesie i osuszania go celem połączenia zachodnich centrów przemysłowych ze źródłami surowców środkowej i wschodniej Europy, Warszawa 1925.

S. Turc zy now i c z, T. Tilling er: The transeuropean waterway through Poland: by way of Polesie - its natural gate - and the necessity of draining that territory, Warszawa 1925. 